\title{
UN ARTE DE LA PALABRA \\ EN LA CATALUÑA DEL SIGLO XII ${ }^{1}$
}

AlFons PUIGARNAU

Universitat Pompeu Fabra

(Barcelona)

\section{SUMARIO}

1. La Edad Media como edad de la Palabra.- 2. Una Palabra activada por la Memoria.- 3. El juramento como memoria del poder.- 4. El juicio como memoria del Verbo.- Conclusión.

El título de este artículo plantea abiertamente un problema historiográfico. La pregunta que abre es: ¿desde qué punto de vista y con qué materiales se va a hablar de la Cataluña del siglo XII? Es un interrogante particularmente apropiado para un monográfico sobre el siglo XII preparado para publicarse en el año 2000. Estas páginas quedarán cronológicamente colocadas en un volumen a caballo entre el siglo XX y el XXI, una época de transición y tal vez, por esta misma razón, formando parte de una historiografía de transición. Se puede rechazar el supuesto de que el historiador del arte que abandona el segundo milenio para embarcarse en la aventura del tercero sea un hombre de transición. Sin embargo, en estas páginas no hemos podido evitar posicionarnos y sentirnos en un terreno de paso hacia los nuevos retos

'Abreviaturas más frecuentemente utilizadas: ACA (Arxiu de la Corona d'Aragó), PBN (Paris Bibliothèque Nationale), LFC (Liber Feudorum Ceritaniae), LFM (Liber Feudorum Maior), CR (Catalunya Romànica), PL (Patrologia Latina).

"Anuario de Estudios Medievales", 30/2 (2000) 
que va a plantear el estudio de las fuentes primarias en la historia y en el arte en los próximos decenios.

El gran historiador de la cultura Jacob Burckhardt representa también una figura de transición entre la historiografía del siglo XIX y la del XX. El problema con el que se encuentra entre mediados del siglo XIX y la primera década del XX es que una presunta "ciencia" sólo podía hacerse valer en la medida en que aparentase distanciarse de la especulación filosófica y, por tanto, del idealismo sistemático ${ }^{2}$. Vive, claramente, una época de transición, en la que debe bascular entre dos peligrosos polos: el positivismo de la presunta "ciencia" y el idealismo de la presunta "filosofía". A él se debe la obra más próxima a la síntesis que por entonces se andaba buscando: la historiografía del arte como parte fundamental de la historia de la cultura, la visión de las artes plásticas como pieza básica en el despliegue del Espíritu. Lo que de esta manera se imponía era el liberalismo historiográfico, la actitud más apropiada para una época de transición. Quizás la novedad que plantea Burckhardt -y como él, cada uno a su manera, Dilthey, Nietzsche, Simmel o Cassirer- es la "ontología del presente". Cada uno de ellos responde de modo diverso a la pregunta: ¿qué pasa en esta cultura? o ¿cuál es el sentido de lo que acontece? Y el modo en que lo resuelven es estableciendo comparaciones entre su cultura del presente y la de algún otro pasado como Grecia o el Renacimiento. La solución que Burckhardt plantea es que en el Renacimiento italiano coinciden el resurgir de las artes y de las letras con el nacimiento de la individualidad artística en sentido amplio ${ }^{3}$. La tesis de fondo es que "surge con toda su fuerza la idea de lo subjetivo; el hombre se convierte en un individuo espiritual" .

Para escribir el presente artículo, los trabajos de Burckhardt son un buen modelo porque también nosotros nos encontramos en un momento de transición. Se está cerrando el período de la historiografía en el que entre los años 50 y 60 de nuestro siglo XX, el resultado del análisis del hecho histórico ha sido parcial: se ha visto al hombre como algo impenetrado, como muerto,

${ }^{2}$ J.F. YVARS, La formación de la historiografia, en V. BozAL (ed.), Historia de las ideas estéticas y de las teorías artísticas contemporáneas, vol. I, Madrid, Visor, 1996, p. 140.

${ }^{3} \mathrm{G}$. VILAR, La filosofia de la cultura, en BozAL, 1996, p. 365.

${ }^{4} \mathrm{~J}$. BURCKHARDT, La cultura del Renacimiento en Italia, Barcelona, Zeus, 1968, p. 125. 
sin espíritu ${ }^{5}$. Ciertamente, basta con decir que la historiografía de cuño marxista ha perdido parte de su credibilidad para encontrar reacciones de crítica a una visión más culturalista del hecho histórico. Es posible que eso equivalga a decir que no estamos en un período de transición en la historiografía entre el pasado siglo y el presente. Para los críticos de esa visión culturalista, el descubrimiento de Burckhardt de la naturaleza "como una imagen dotada de mayor o menor belleza y objeto de disfrute" ${ }^{\text {no sería un }}$ nuevo modo de ver la historia, sino un producto más de la imaginación creativa. Pero hoy agradecemos a la obra de Burckhardt que nos brindase una observación poética del paisaje, más allá del hecho - historicista- de ser el escenario del batallar diario para ganar el pan con el sudor de la frente. Por primera vez la naturaleza no es sólo el escenario de las actividades humanas sino que es considerada estéticamente.

Para trabajar como historiadores de transición de un siglo a otro no se debe renunciar a dos elementos fundamentales de los que no prescindirán ni Jacob Burckhardt ni otros grandes nombres como Franz Wickhoff, Aloïs Riegl, Max Dvorák, Julius von Schlosser o Hans Sedlmayr. Primero hacen falta copiosos materiales. Segundo, grandes ideas motrices que den vida al aparato documental que se maneja. Es posible que esto haya abundado poco en la historiografía del arte catalán. Para su Die Kultur der Renaissance in Italien el propio Burckhardt recopila setecientos extractos de las Vidas de Vasari. Similares cantidades de documentación recoge de otras obras como las Memorias de Vespasiano o la Autobiografia de Cellini. Lo impresionante no es el volumen de fuentes que maneja sino la economía con que las utiliza, y el toque mágico que da a cada una de sus citas, utilizándolas como expresiones de verdaderos signos de los tiempos. Nadie puede acusarle de no haber advertido a sus lectores acerca del criterio subjetivo con que seleccionó sus fuentes. En el primer párrafo de su libro, al que llama ensayo en el sentido original del término, dice: "Las líneas maestras de un período y su mentalidad pueden presentar un aspecto diferente para cada espectador, y los mismos estudios que conducen a este libro podían haber conducido a otro de conclusiones esencialmente diferentes". Utiliza materiales y además, grandes

${ }^{5}$ Cf. J. Aurell; A. Puigarnau, La cultura del mercader en la Barcelona del siglo XV, Barcelona, Omega, 1998

${ }^{6}$ BURCKHARDT, 1968, p. 259. 
ideas que den vida a la gran cantidad de fuentes que maneja. Con esto, el historiador suizo-alemán se enfrentó al programa del historicismo positivista de Ranke y defendió que "la historia es y continúa siendo poesía en su más alta expresión"7.

El trabajo que aquí se propone es tratar de armonizar una Historia y una Filosofía de la cultura en la Cataluña románica. Interesa construir un discurso hermenéutico sobre la historicidad, de modo que se que dé voz a los protagonistas de esta Historia. En estas páginas se encontrará una variedad de pequeños elementos que como fragmentos de un rompecabezas dibujan, juntos, una realidad histórica: un verdadero Arte de la Palabra, que subyace a tres elementos históricamente puros: 1 . El pacto feudovasallático; 2 . La iconografía del juicio final; y 3 . La presencia de una mentalidad apocalíptica. Estos tres elementos se dan juntos en una Cataluña que en el siglo XII experimenta un importante renacimiento cultural. En este trabajo se postula, como hábito mental de esta época, una facilidad para "recordar inventivamente", un verdadera "Memoria creativa" que posibilita la actividad y la actualidad de una Palabra de fuerte sabor cristológico. Intentaremos encontrar en cada detalle fáctico el principio general que bajo él subyace. Así es como se supone que se podrá hacer una verdadera Kultursgechichte, en el sentido en que Gombrich utilizaba esta palabra: manejar materiales concretos, datos, y reuniéndolos sacar conclusiones acerca de un período histórico, y no sólo de un 'movimiento' en el sentido hegeliano de la expresión'.

\section{LA EdAD MEDIA COMO EDAD DE LA PALABRA}

Posiblemente la Edad Media, antes de llegar al siglo XII, sea uno de los períodos más desconcertantes de la Historia universal. Es una etapa en la que no ha cristalizado, nítidamente, un ideal de hombre. Las relaciones Iglesia-Estado no han sido formuladas con claridad: aún no se han deslindado los intereses laicos de los eclesiásticos. La ciencia, hasta llegar a la época Moderna, no hallará un estatuto definitivo y aun después del Renacimiento son muchos los replanteamientos que sufrirán las relaciones entre razón y fe,

${ }^{7}$ J.F. Yvars, Jacob Christoph Burckhardt, en BozAL, 1996, p. 378.

${ }^{8}$ E.H. GomBrich, In Search of Cultural History, London, Oxford University Press, 1969. 
filosofía y teología, ciencia y religión. Es cierto que este período de la historia ha sido estudiado con empeño desde el campo de la filosofía, el arte, la sociología, el derecho, la literatura. Hay mucho camino andado. Pero todavía son muchos los cabos que quedan por atar.

A veces el historiador se pregunta cuál ha sido el destino de la Palabra en la Edad Media. Porque es posible que estudiando sus avatares y sus múltiples sentidos, se pueda dar un paso más en la comprensión de este mundo enigmático, fascinante y lleno de símbolos, que constituye el imaginario literario y artístico del medioevo. En este tránsito que la Palabra sufre entre ella misma y el Silencio ocurren muchas cosas. Hay muchas palabras y variados silencios. Cronológicamente, antes que la palabra griega se conoce la hebrea, que marca un importante precedente en la historia, precisamente, de las religiones del Libro: es una Palabra revelada y esperada 9 También el Logos griego establece pautas de cultura fundamentales para comprender la narración del prólogo de cuarto Evangelio: racionalizar, mediante el término 'logos' el hecho fundamental de que Dios establezca su morada entre los hombres (cf. Juan 1,14). Este acontecimiento es el que, comentado a lo largo de la Edad Media, consolida una cultura estética cristiana. Tal vez sea éste el sentido principal de la Palabra en la Edad Media cristiana y, sin duda, el que se encuentra en el arte y la documentación del siglo XII en Cataluña.

También la Palabra cristiana tiene sus silencios, el Verbo se oculta y esta ocultación se manifiesta estéticamente, a lo largo de la historia medieval. Son esos avatares de la Palabra, llamada a pronunciarse a veces, y con frecuencia a silenciarse. Escribir un ensayo sobre la Palabra es exponerse a un discurso lleno de ambigüedades: al leer estas líneas es posible que se alce en el lector la queja interior porque una reflexión sobre la Palabra induce a pensar no sólo en el Verbo de Dios encarnado en Cristo. Es difícil delimitar bien los sentidos de la Palabra. Sin embargo, en el presente artículo, se pondrá el acento en algunos de los aspectos que parecen más significativos del siglo XII catalán. En concreto, interesa destacar su relación con tres conceptos clave: el Juramento, el Juicio y el Tiempo. La Palabra propia del siglo XII en la Cataluña condal es, en resumen, eminentemente cristológica. Lo que se

${ }^{9} \mathrm{~J}$. Gutmann (ed.). The Image and the Word. Confrontations in Judaism, Christianity and Islam, Missoula, Montana, Scholars Press for American Academy of Religion, Society of Biblical Literature, Religion and the Arts, 1977. 
pretende en estas páginas es explicar el Juramento como memoria de esta Palabra generadora de poder feudal. El pacto feudovasallático es una ceremonia sacramental, que remite a la Palabra de Dios. Es un pacto generador y estructurador de una malla social de poder. Es fundamental considerar el Juicio como memoria soteriológica. Es preciso recordar la primera Palabra en Cristo: el bautismo. Esta "memoria sacramentalbaptismal" remite, ciertamente, a un Juicio final. Los programas iconográficos del Apocalipsis son una memoria, un recuerdo de nuestros orígenes y una remisión a nuestras postrimerías: despiertan una memoria y apuntan a un final de los tiempos. Siempre hay un Alfa y un Omega: nadie escapa a este sino. Finalmente, la Memoria del Juramento y del Juicio va siempre ligada al Tiempo. El tiempo es la Memoria de la Palabra: acordarse del Verbo es lo que mide el tiempo. Así se vinculan el Juramento, el Juicio y el Tiempo: mediante el Anno domini, en el que cristaliza definitivamente esta Memoria de la Palabra en la Cataluña del siglo XII.

La Palabra vertebra dos ámbitos y los entrelaza y armoniza: el Juicio y el Juramento. A su vez, estos dos ejes configuran la dimensión fundamental de la Palabra, que es el Tiempo. El juramento es una palabra "de ida", mientras que el Juicio lo es "de vuelta". En la Edad Media todo hombre, toda mujer, sabe que tras el juramento vendrá el juicio. Por eso la iconografía de la relación feudovasallática, que estamos acostumbrados a examinar en las páginas del Liber feudorum maior, es una iconografía de la Palabra humana que se entrelaza con la divina. La estampa de un vasallo sometiéndose a su señor que le promete protección forma parte de un imaginario místicosimbólico, del mismo modo que la imagen apocalíptica de la Maiestas que, desde su almendra de luz, emite el juicio eterno sobre los hombres. Así quedan entrelazadas la Palabra del Juicio con la del juramento y enmarcadas en el arco temporal que dibuja el Alfa y la Omega.

Esta Palabra, que en el Antiguo Testamento es prometida y en el Nuevo es hecha carne, recibe una brillante expresión durante los largos siglos de la Patrística. Los Padres de la Iglesia anotan, comentan y refrescan esa Palabra con elementos de diversas tradiciones, fundamentalmente grecorromanos y judíos. Sería difícil seleccionar unos Padres y prescindir de otros. Pero no hay duda de que Agustín de Hipona y Juan Escoto Eriúgena son recibidos 
en la Cataluña del XII, e incorporados a la vida litúrgica de los condados ${ }^{10}$. De esta patrística brotará una expresión apoteósica de la Palabra cristiana, ya formulada como verdadera Teología. Es una teología polifacética que se resume en dos aspectos fundamentales: el cosmológico, como observación del mundo y el místico como observación del Creador.

Ni el juicio ni el juramento son palabras propias sólo de teólogos o de señores feudales. La sociedad del siglo XII es la sociedad de la Palabra porque este verbo, por decirlo así, está al cabo de la calle. El pueblo sufre con esta palabra, la ve esculpida en los tímpanos de sus iglesias, la ve pintada en las bóvedas de sus ermitas y catedrales, la canta en dramas medievales como el de la Sibila Eritrea. Porque los avatares estéticos de la palabra forman parte de una auténtica cultura que entronca todos estos elementos: Apocalipsis, Majestad, Poder, feudovasallaje, drama, música y arte. A lo largo de estas páginas trataremos de explicar las incidencias de la Palabra como estructuradora de una verdadera cultura estética en la Cataluña del siglo XII.

La Palabra, habitualmente, tiene una mediación estética que, en los términos de la cultura cristiana de la época es la cultura de la luz. Tras la cultura de la creación aparece clara la palabra del Fiat Lux; tras la cultura de la Biblia aparece clara la Palabra de la Lux mundi. Escoto Eriúgena lo expresa, en una época cercana a los orígenes del feudalismo, del siguiente modo:

Podemos decir que la razón más primaria de todas las cosas, que es simple y múltiple, es Dios la Palabra. Porque es llamada por los griegos Logos, que es Palabra o Razón o Causa. Lo que está escrito en el Evangelio griego debe ser interpretado 'En el principio era el Verbo' o: 'En el principio era la Razón', o: 'En el principio era la Causa'. Porque nadie que afirme esto se desviará de la verdad. Porque el primogénito Hijo de Dios es a la vez Palabra, Razón y Causa (...) Porque Él es la Palabra del Padre. Entonces, el Hijo de Dios, al ser Palabra y Razón y Causa, se puede decir que es la Razón creativa y la Causa del universo establecido, simple y en sí mismo infinitamente múltiple, es decir, la Palabra de Dios ${ }^{11}$

${ }^{10} \mathrm{~A}$. Puigarnau, "Vox spiritualis aquilae" y "maiestas domini" en el siglo XII, en J. AzANZA; V. BALAGUER; V. Collado (ed.), "V Simposio bíblico español. La Biblia en el Arte y en la Literatura", Pamplona-Valencia, 1999, pp. 339-351.

"PL 122, 642. 
Este es el concepto eriugeniano de la Causa primordial: una Palabra creadora y creada en el Hijo, que no es creado sino engendrado. Por esta razón, debe ser una Palabra asociada a una Teología de la Luz/Tiniebla que, al desplegarse en el mundo, marque la pauta del Tiempo (Alfa/Omega), defina un horizonte redentor (Apocalipsis) y reúna a los hombres bajo un poder originado en esa misma Palabra (pacto feudovasallático).

\section{UNA PALABRA ACTIVADA POR LA MEMORIA}

Como en el resto de Europa la Edad Media en Cataluña es una época marcada por los avatares culturales de una Palabra cristológica. Sin embargo, lo que otorga todo el peso al Juramento feudal, al Juicio final y al Tiempo absoluto es la Memoria. El recuerdo recrea, por decirlo así, los avatares de la Palabra. Cuando el hombre se dispone a actualizar su pacto feudal para defender a su señor, lo hace en virtud de una Memoria: recuerda su compromiso. Cuando ese sujeto se arrepiente y confiesa sus pecados es porque le viene a la memoria el peligro de no salvarse, su apocalipsis personal. Las categorías mentales de la época (fidelidad, amor, pecado, belleza, vida, mundo, hombre, Dios...), derivadas de la Palabra, se activan por el recuerdo. $Y$ no sólo se activan sino que una memoria creativa las potencia, las engrandece y las estructura en la praxis de una religión poderosa.

Cualquier trabajo sobre la Memoria debe remitirse al The Art of Memory ${ }^{12}$ de Francis Yates, importante generador de otros materiales sobre el tema ${ }^{13}$. Sin embargo, en el presente contexto conviene insistir en que el

\footnotetext{
${ }^{12}$ London, Routledge and Kegan Paul, 1966. También F. YATES, Architecture and the Art of Memory, "Architectural Association Quarterly", 12 (1980), pp. 4-13.

${ }^{13} \mathrm{M}$. CARruthers, The Craft of Thought. Meditation, Rhetoric, and the Making of Images, 400-1200, en "Cambridge Studies en Medieval Literature", 34, Cambridge, Cambridge University Press, 1998; J. ANNAS, Aristotle on Memory and the Self, en: M.C. NuSSBAUM and A.O. RORTY, eds. "Essays on Aristotle's 'De Anima'", pp. 297-311, Oxford, Clarendon Press, 1992; J. ANNAS, Memories are made of this and that, en "London Review of Books", 14 May 1992, pp. 21-22; J.-Ph. ANTOINE, Ad perpetuam memoriam: Les nouvelles fonctions de l'image peinte en Italie, 1250-1400, en "Melanges de l'Ecole française de Rome", 100 (1988), pp. 541615; H. BluM, Die Antik Mnemotechnik, Spudasmata, 15, Hildesheim, Georg Olms, 1969; L. BolzoNI, Il teatro della memoria: studi su Giulio Camillo, Padua, Liviana, 1984; L. BolzoNi; P. CORSI, eds., La cultura della memoria, Bologna, Il Mulino, 1992; M CARRUTHERS, 'Locus tabernaculi': Mémoire et lieu dans la méditation monastique, en "Cahiers de la Villa Gillet", Lyon, cahier spécial, 1996, pp. 7-36; C. GIBSON-WOOD, The Utrecht Psalter and the Art of Memory, "Revue d'Art Canadien/Canadian Art Review" (RACCAR), 14 (1987), pp. 9-15; H.
} 
recuerdo no es sólo una cualidad mnemotécnica, como era entendida en algunas obras de Cicerón. Los pensadores del medioevo toman su De inventione como la Primera Retórica, considerando la Rhetorica ad Herennium, entonces atribuida a él, como la Segunda o Nueva Retórica. Esta última era el libro de texto que describía el arte de la memoria como un plan de construcción de una casa familiar en cuyas estancias un orador debía "colocar" imágenes que le sugirieran el material sobre el que disertar. Muchos pensadores se han hecho deudores del trabajo de Yates, como precedente para el estudio de la memoria retórica. Sin embargo, precisamente por su carácter pionero, viene a reforzar algunas desviaciones respecto de los posibles usos cognitivos del "arte de la memoria" y sobre la naturaleza de su influencia al generar las imágenes y los "lugares" para lograr este objetivo. El problema principal radica en que Yates considera este arte de la memoria como repetición mecánica de un material previamente almacenado. Es peligroso caracterizar las versiones medievales del arte antiguo como "estáticas", sin movimiento, como "pensamiento prisionero" ${ }^{14}$. Pero si la Memoria debe activar el Juramento, el Juicio y medir el Tiempo, no puede contener simplemente un conjunto de elementos a repetir incansablemente sino que debe ser un punto de partida para reelaborar, para inventar. De esta manera, la memoria se erige en un "arte composicional" 15 .

Las artes de la memoria están especialmente implicadas en la adopción de cualidades como la "imaginación" y la "creatividad". Por esta razón la Memoria de la Palabra en la Cataluña del siglo XII será un potente generador de iconografía en un momento de fuerte producción artística en el Principado, posiblemente asociado al Renacimiento cultural que por estas épocas experimentan también otras zonas de la Europa medieval ${ }^{16}$. Es importante ver que este rebrote de cultura en el siglo XII catalán va emparejado a un espíritu de Reforma que impregna la cultura monástica de la época. La reparación y redecoración de iglesias puede poner de relieve la renovación

HADJU, Das mnemotechnische Schriftum des Mittelalters, 1936; G.B. MATTHEWS, Augustin On Speaking from Memory, 1965; F. WALLIS, The Ambiguities of Medieval 'Memoria', en 'Canadian Journal of History/Annales canadiennes d'histoire", 30 (1995), pp. 77-83.

${ }^{14}$ YATES, 1966, p. 178 y 1980, p. 7.

${ }^{15} \mathrm{Cf}$. S. CROWLEY, The Methodical Memory: Invention in Current-Traditional Rhetoric, Carbondale, IL, Southern Illinois University Press, 1990.

${ }^{16}$ Bibliografía sobre este renacimiento del XII en Europa: E. PANOFSKY, Renacimiento y renacimientos en el arte occidental, Madrid, Alianza, 1988, p. 100, nota 21. 
o el renacimiento de esta sociedad, también manifestada en la llamativa vegetación de la escultura en los claustros catalanes del siglo XII. Es el mismo momento en el que la música establece su autonomía con respecto al saber matemático y es reconocida la voz humana en sí misma, en sintonía con las necesidades religiosas del momento ${ }^{17}$. Incluso las canciones de los pájaros son reconocidas como una llamada a la vida religiosa por Miró de Ripoll ${ }^{18}$. Cada vez más, el arte habla desde los murales de las iglesias como a través de pequeñas pinturas y esculturas, conservadas en oratorios, celdas y hogares familiares anónimos. Los fundidores de bronce y esmaltadores de Limoges suministrarán por toda Europa crucifijos y otros objetos, constituyendo una poderosa manifestación de este arte de la memoria, que ayuda a explicar la fecundidad estética de esta época.

\section{EL JURAMENTO COMO MEMORIA DEL PODER}

La Cataluña del siglo XII ha sufrido un proceso de feudalización de importantes consecuencias socioeconómicas. Hay quien en el feudalismo catalán sólo ha visto un cruce de palabras entre señor y vasallo casi dialéctico, sujeto a las pasiones del poder y de la lucha de clases. Es lógico que la palabra, en una relación feudovasallática haya generado vinculaciones económicas. Pero estas relaciones de poder se entrelazan con "la otra Palabra", es decir, la Palabra revelada. Es difícil negar la presencia de un elemento "verbal-sacramental" en la ceremonia de feudovasallaje que fundamenta una relación bilateral de poder hasta la extinción de una de las partes. El vínculo no se agota en una mera simbiosis económica o social entre dos personajes, sino que alcanza una dimensión religiosa que constituye uno de los más interesantes avatares de la Palabra en la Edad Media. Los juramentos feudales son una prueba fehaciente de que la palabra tiene fuerza no sólo lógica sino ontológica, a través de la estética. Sólo así se puede

${ }^{17} \mathrm{H}$. ANGLÈs, La música a Cataluña fins al segle XIII, Barcelona, Diputación de Barcelona, Publicaciones de la Sección de Música de la Biblioteca de Cataluña, 1935; H. ANGLÈs, La musique en Catalogne aux $X^{e}$ et $X I^{e}$ siècles. L'École de Ripoll, en "La Catalogne à l'époque romane". Conférences données en 1929-1930 à la Sorbonne. París, 1932, pp. 157-179.

${ }^{18}$ G.B. LADNER, Vegetative Symbolism and the Concept of Renaissance (1961), reproducido en Images and Ideas in the Middle Ages: Selected Studies in History and Art, Rome, Storia letteratura. Raccolta di Studi e testi 155-156, 1983, pp. 727-763. 
entender sobre qué objetos, por ejemplo, juran los vasallos: "per coronam", "per grana incensi", "per librum missalem", "per librum evangelium et calicem", "cum libro regulea et cum regula", "per textum evangelium"; y a la vez juran por cosas de la naturaleza, la otra 'Palabra' posible: "per lignum", "per herbam et terram", "per ramum et cespitem"19.

A fines del siglo XII puede hablarse del sistema de gobierno en Cataluña como 'monarquía feudal': un reino cuyo gobernador, Ramón Berenguer IV, explota sistemáticamente los derechos feudovasalláticos para incrementar su poder ${ }^{20}$. Esta imagen que ofrece la historia se puede tener en cuenta aisladamente, sin más connotaciones, o verla a la luz de esta sección del trabajo, a la luz del Juramento. Es el compromiso lo que ha aglutinado, en última instancia, el poder condal alrededor de la Casa de Barcelona, junto al conde que habrá unido Cataluña al reino de Aragón. Una sociedad que, en el tiempo de Ramón Berenguer I aparecía débilmente estructurada y sin una conciencia de Estado aparece, tras unas décadas de compromisos feudovasalláticos, como un cuerpo social con capacidad de expansión: así se encargará de demostrarlo la historia del Principado a lo largo del siglo XIII.

El incremento de la iconografía de la Majestad de Cristo-luz se produce paralelo al auge de la institución feudovasallática. Se trata de ver de qué modo conectan esta teología de la luz con una, por llamarla así, atrevidamente, 'teología del vasallaje'. No ha sido frecuente tratar el tema del vasallaje arrancando desde el punto de vista de su ritual simbólico, cosa que propone hacer Le Goff desde una perspectiva histórico-antropológica ${ }^{21}$. La iconografía del Pantocrátor en una mandorla de luz es un tema que se desarrolla con fuerza en Cataluña entre el siglo XI y mediados del XII. La institución política del feudalismo arranca en Cataluña tras un hiato histórico en que el esclavismo ha desaparecido y el feudalismo es todavía inexistente; esto ocurre entre la segunda mitad del siglo X y el primer tercio del XI. Durante este período parece como si las mutaciones sociales estuvieran en suspenso y se quisiera desarrollar un régimen de libertad cada vez más

${ }^{19}$ Du CANGE, Glossarium ad scriptores mediae et infimae latinitatis (1733 ed.) 3, col. 1533, art. Investitura

${ }^{20}$ T.N. Bisson, Feudalism in Twelfth Century Catalonia, en Medieval France and her Pyrenean Neighbours. Studies in Early Institutional History, London-Ronceverte, The Hambledon Press, 1989, p. 170.

${ }^{21} \mathrm{~J}$. LE GoFF, Time, Work and Culture in the Middle Ages, Chicago-London, The University of Chicago Press, 1980, pp. 237-287. 
acentuado. Se trata de un momento histórico en el que en la Europa del momento la mayoría de los hombres viven en condiciones de dependencia y en parte de servitud. La situación en Cataluña es una paradoja explicable por el papel decisivo que juega este campesinado independiente tanto en relación a la defensa del país como a la conquista de nuevas tierras. Sin embargo, no es una situación destinada a alargarse en el tiempo, por ser inaceptable, de hecho, para la aristocracia dominante ${ }^{22}$. Una serie de factores favorecen la instalación del feudalismo en Cataluña, concretamente entre 1030/1040 y 1060, asegura Pierre Bonnassie; o hacia el 1020, según Thomas N. Bisson ${ }^{23}$. La cuestión es que en la primera mitad del siglo XI el feudalismo en Cataluña es ya una realidad. Esto significa que a mediados del XI y a inicios del XII están cristalizando las relaciones feudo-vasalláticas entre personas de distinto rango social, y al mismo tiempo esas relaciones están tejiendo un nudo de poder en torno a la persona del conde de Barcelona Ramón Berenguer I (10351076). Antes del 1150 se produce un proceso de expansión del feudalismo catalán en dos direcciones: hacia el norte, en el área occitana; hacia el oeste y el sur-oeste, Lleida y Tortosa.

Esta situación histórica tiene una materialización concreta en los términos de un arte de la Palabra: ya el 1067 Ramón Berenguer I ha recibido 35 juramentos de fidelidad por parte de ciertos nobles de Carcassès y Razès ${ }^{24}$; en 1113 Ramón Berenguer III habrá recibido otros 89 juramentos por parte de castellanos provenzales ${ }^{25}$. Estos sacramentalia son absolutamente conformes en los términos de los juramentos que en ese momento se exigen a los vasallos

${ }^{22} \mathrm{P}$. BONNASSIE, Sur la formation du féodalisme catalan et sa première expansion (jusqu'à 1150 environ), en J. PORTELLA I COMAS (ed.), La formació $i$ expansió del feudalisme català, "Actes del Col-loqui organitzat pel Col-legi Universitari de Girona (8-11 de gener de 1985), Homenatge a Santiago Sobrequés i Vidal", (= "Estudi General, Revista del Col-legi Universitari de Girona" Universitat Autònoma de Barcelona, n 5-6, Girona, 1985-1986, p. 10.

${ }^{23}$ T.N. BISSON, Feudalism in Twelfth Century Catalonia, en Medieval France and her Pyrenean Neighbours. Studies in Early Institutional History, London-Ronceverte, The Hambledon Press, 1989, pp. 153-178.

${ }^{24} \mathrm{LFM}, \mathrm{II}, \mathrm{n}^{\circ} 838$, BONNASSIE, 1985, p. 20, nota 60.

${ }^{25} \mathrm{LFM}, \mathrm{II}, \mathrm{n}^{\mathrm{0}} 878$. Además, sobre los juramentos recibidos por los condes Ramón Berenguer I, Ramón Berenguer III y Ramón Berenguer IV, ver: M. ZIMMERMANN, Aux origines de la Catalogne féodale: les serments non datés du regne de Ramon Berenguer I, en J. PORTELLA I COMAS (ed.), La formació $i$ expansió del feudalisme català, "Actes del Col.loqui organitzat pel Col-legi Universitari de Girona (8-11 de gener de 1985)", cit. p. 109; E. MAGNOU-NORTIER, Fidelité et féodalité méridionales d'après les serments de fidelité ( $X^{e}$-début $X I^{e}$ siècle), en Les structures sociales du Languedoc, de l'Aquitaine et de l'Espagne au premier âge féodal, Paris, CNRS, 1969, pp. 115-142. 
catalanes: por una parte, implican el homenaje ${ }^{26}$, por otra, la mención de las obligaciones positivas del fiel: tenere, aiudare, defendere, guerreiare ${ }^{27}$. Junto a estas evidencias de consolidación del régimen feudal, habría que mencionar las arqueológicas ${ }^{28}$. Se trata de una 'liturgia del juramento', compleja y contradictoria porque asocia la práctica oral del juramento sobre una res sacra y la redacción de un texto escrito que toma, a la vez, la forma de un documento notarial. En la imagen del convenio sobre el castillo de Cardona aparecen el obispo Folch de Urgel y el conde Guillem Ramón de Cerdaña (fig. 1) ${ }^{29}$. La iconografía de estos personajes evidencia tres elementos que forman parte del simbolismo del ritual vasallático según lo plantea Le Goff: la palabra (el juramento oral), el gesto (la mezcla de las manos, immixio manuum) y el objeto (el libro que sostiene el tercer personaje, interpuesto entre los dos principales) ${ }^{30}$.

Por ahora interesa centrarse en el acto mismo de la prestación de homenaje. El señor y el vasallo se intercambian ciertos discursos, interpretan diversos gestos y se dan o reciben determinados objetos que, por citar la definición que san Agustín da al signum-simbol, "añadiéndose a la impresión que producen en nuestros sentidos, comunican algo que va más allá de nuestro conocimiento". Siguiendo a Ganshof, la ceremonia tiene una primera fase, hominium, que está constituida por dos actos. El primero es verbal: una declaración del vasallo, manifestando su voluntad de ser el hombre del señor. "Iuramus nos Berengarius et Gulielmus, filii Tedlena... ad te..." ${ }^{31}$. Es común que dos hermanos o una pareja juren fidelidad al señor al mismo tiempo.

Se trata de una promesa de fidelidad: se formula en el tiempo presente, es inmediatamente creadora de obligaciones, no debe haber dudas

${ }^{26}$ LFM, II, 839: ipse vicecomes fiat homo de predicto vicecomite Raimundo et iuret ei fidelitatem (Carcasonne, 1068); LFM, II, 885: facio inde tibi hominium et fidelitatem et iuro tibi mea propria manu (Provence, 1154), BONNASSIE, 1985, p. 20, nota 62.

${ }^{27}$ Ejemplos en LFM, II: para Languedoc, $n^{\circ} 827,830,831,837$; para Provenza: $n^{0} 879$, 881, 884, etc.

${ }^{28} \mathrm{M}$. RIU, L'aportació de l'arqueologia a l'estudi de la formació $i$ expansió del feudalisme català, en J. PORTELLA I COMAS (ed.), La formació i expansió del feudalisme català, cit. pp. 27 47.

${ }^{29} \mathrm{LFC}$, fol. 6d. Cf. LFM, II, lám. VI

${ }^{30}$ LE GOFF, 1980, p. 239.

${ }^{31} \mathrm{LFM}, 136$. 
entre los contrayentes, no es admisible mediación alguna. Después del compromiso, el que jura certifica su fidelidad 'negativamente': sine fraude et malo ingenio et ulla deceptione, afirmaráa ${ }^{32}$. Obviamente, es una relación verbal simbólica, en la que tanto la pregunta del señor al vasallo sobre si quiere ser su hombre, como la respuesta afirmativa del vasallo, van más allá de la formalidad, por llamarla así, estética, del intercambio verbal. La immixio manuum completa el acto. El vasallo ofrecerá las manos cerradas al señor y éste las aceptará cerrando las suyas sobre las del vasallo: in manu nostra trustem et fidelitatem, reza una antigua fórmula ${ }^{33}$. El gesto del vasallo no es suficiente: debe ser correspondido por el del señor. Con la 'fusión de las manos' se está tocando un importante capítulo del simbolismo medieval y universal. Se trata de un simbolismo polisémico, que expresa la instrucción, la defensa, el juicio. Pero, de modo muy especial, expresa protección y aun el encuentro entre el poder y la sumisión. El gesto revive la imagen de la terminología legal romana devolviendo a la manus su verdadero alcance como una de las expresiones de la potestas y, en particular, uno de los importantes atributos del paterfamilias ${ }^{34}$. En el Liber feudorum maior abundan las imágenes de la immixio manuum. Desde los juramentos casi estereotipados (fig. 2) (5) $^{35}$ donaciones (fig. 3$)^{36}$, pactos de mútua ayuda (fig. 4$)^{37}$, entregas de dotes esponsalicias (fig. 5) ${ }^{38}$, cesiones de derechos (fig. 6) ${ }^{39}$, juramentos de

${ }^{32}$ ZiMMERMANN, 1985, p. 114.

${ }^{33}$ Formulae Marculfi, I, 18, en: Monumenta Gercaniae Historica, Formulae Merowingici et Karolini aevi, ed. ZEUMER, part 1 (1882), p. 55. Citado por LE GoFf, 1980, p. 241.

${ }^{34} \mathrm{P}$. OuRliAC; J. DE MALAFOSSE, Droit romain et Ancien Droit, I, Les Obligations, Paris, 1957; E. VOLTERRA, Istituzioni di diritto privato romano, Roma, 1961.

${ }^{35}$ Escena típica de prestación de homenaje, LFM, fol. 85, CR XX, p. 202.

${ }^{36} \mathrm{El}$ conde Bernat Tallaferro de Besalú hace donación de los castillos de Tautavel y Pena a su hijo y futuro sucesor en el condado, Guillem I (LFM fol. act. 61a), CR XX, p. 62.

${ }^{37}$ Los dos Alfonsos, el Casto y el de las Navas, pactan mútua ayuda. Tratado de Zaragoza, julio de 1170, LFM, fol. act. 19, CR XX, p. 198.

${ }^{38} \mathrm{El}$ vizconde Bernat Ató de Béziers y Cecilia, su esposa, entregan, juntamente con su hija Ermengardis, varios feudos, como dote esponsalicia, al futuro conde Gausfred III, de Rosellón, LFM, fol. act. 78v, CR XX, p. 200.

${ }^{39}$ Acto de entrega de dos mil onzas de oro, hecha por Ramón Berenguer I y Almodis, su esposa, al conde Guillem Ramón de Cerdaña y a Adelaida, su esposa, por la cesión de sus derechos sobre Carcasona, LFM, fol. act. 83bis., XX, p. 201 
fidelidad por parte de altos eclesiásticos (fig. 7) ${ }^{40}$ o entre magnates laicos (fig. $8)^{41}$.

Sin embargo, hay un elemento particular, el más importante, que confiere validez ontológica al compromiso feudovasallático, y que lo arrastra al dominio de lo sagrado: el sacramento. Tras los pasos de cualquier ceremonia feudovasallática, quien obtiene el beneficio y quien recibe el vasallaje se están intercambiando una gracia. Este es el elemento principal del juramento, que lo dota de una fuerza especial y que, en última instancia, se mezcla, para bien o para mal, con el elemento de carácter señorial. De esto es consciente el vasallo y el señor ${ }^{42}$. Cada uno a su manera son conscientes de estar participando, en ese juramento, de un intercambio de palabras que tendrán consecuencias concretas. El vasallo sabe que después del juramento, pasado el tiempo, vendrá el juicio; el señor conoce bien que se le pedirá cuenta estrecha, se le juzgará por su correspondencia, en términos de protección, gratificación y ayuda, respecto del vasallo. Incluso los teólogos y artistas que confeccionan los programas iconográficos tendrán en cuenta alguno de los elementos del contrato feudo-vasallático y lo asociarán, sacramentalmente, al misterio cristiano. Para explicar con detalle el entramado de relaciones entre este juramento temporal y el Juicio eterno es preciso observar con detalle una imagen que cubría un lateral de altar, ya a inicios del siglo XIII, cuando la imagen estética del feudalismo en Cataluña hace tiempo que ha cuajado en la cultura de la época. Se trata de la conocida coronación de la Virgen (fig. 9) (3) $^{43}$ pintada por el maestro de Lluçà.

La escena es de una técnica pictórica que, casi, está abandonando la plástica bidimensional del románico. María aparece a la izquierda, sentada a mismo nivel que Cristo, sobre un cojín, en un asiento sin respaldo en simetría con el de su Hijo. Cristo Pantocrátor ha abandonado su mandorla propia,

${ }^{40}$ Juramento de fidelidad prestado por el obispo san Armengol de Urgel al conde Guifré de Cerdaña, LFC, fol act. 9d, CR XX, p. 204.

${ }^{41}$ Los nobles de Perpignan juran fidelidad a Alfonso el Casto, al igual que los castellanos del condado de Rosellón, LFM, fol. act. 82, CR XX, p. 199.

${ }^{42}$ Es preciso tener en cuenta la mención de las res sacrae que el que jura realiza. Por poner algunos ejemplos, que ilustran los motivos del juramento: per Deum et haec sancta (59), per Deum et istarum sanctarum reliquiarum (7), per deum et hos sanctos suos (5), per Deum et istos sanctos (6), per Deum et sanctis suis (7), per Deum et istis sanctis (1), etc. Cf. ZIMMERMANN 1985 , p. 115 .

${ }^{43}$ Vic, Museo Episcopal, HAC, II, p. 201. 
compartiendo un espacio de luz que ya no es geométrico. Va coronado con nimbo crucífero y aparece torsionado hacia la figura de su Madre a quien corona con la mano izquierda y bendice con la derecha. La figura de María se halla en la posición vasallática de la immixio manuum, presentando al Omnipotente sus manos cerradas. La respuesta del Cristo, identificado con la inscripción lateral de IHS.XPS.DNS.NOR (Ihesus Christus Dominus Noster), no es acoger las manos de la Sierva sino coronarla como reza la inscripción lateral a ella: REGINA CELORUM. Además, el artista se ahorra, para nombrar a la Virgen, cualquier tipo de abreviaturas: parece que la presente como a una nueva creatura, la segunda Eva, madre de Dios y de los hombres. Obviamente, la imagen de la immixio manuum es conocida por todos. Además de aparecer en el Liber feudorum maior es grabada sobre algunas monedas de la Europa de la época como el extraño ejemplar numismático de origen polaco, muy influenciado por la numismática bizantina, acuñada en el siglo XII para uso ritual en honor de san Adalberto, y en la que aparece un fiel arrodillado ofreciendo las manos para un homenaje ante el santo obispo (fig. 10) ${ }^{44}$.

En el lado opuesto al panel del altar de Lluçà, sobre dos sitiales pintados siguiendo pautas bizantinas, vuelve a aparecer María, esta vez con las manos abiertas en espera de homenajes por parte de los fieles cristianos, y recibiendo los siete dones del Espíritu santo (fig. 11): SEPTEM DONA SCI SPI. en una actitud completamente frontal. En el halo circular de luz que rodea su cabeza se lee: SPS.SAPIECIA (Spiritus Sapiencia). A su derecha, Juan apóstol que, en postura de tres cuartos, la mira en actitud reverente y muestra su identidad a través de un rótulo que sostiene con la mano izquierda: IOHS. APLS. (Iohannes Apostolus). Finalmente, en la parte frontal del altar, la Maiestas Mariae, que aparece como trono del Logos, rodeada del sol y la luna, sosteniendo en su mano derecha el fruto del Árbol del que comió Eva y, con su Hijo en su regazo, sentada al trono de la Maiestas (fig. 12) ${ }^{45}$. La forma cuatrilobulada que acoge la Theotokos está sostenida por cuatro ángeles. La figura apocalíptica del tetramorfos ha desaparecido, reemplazada por cuatro inscripciones con los nombres de los evangelistas. A ambos lados de

${ }^{44} \mathrm{Ph}$. Grierson, Monnaies du Moyen Age, Fribourg (Suisse), Office du livre, 1976, n. 250.

${ }^{45}$ Frontal de Lluçà (Osona), segunda mitad del siglo XIII, panel central, Maiestas Mariae, MEV 10, CR XXII, 167. 
María, cuatro escenas de su vida: la Anunciación, la Visitación, la Adoración de los Magos y la huida a Egipto.

Hablar del juramento como memoria del poder en la Cataluña del siglo XII es ver hasta qué punto ha cristalizado una imagen iconográfica. Los préstamos iconográficos entre las pinturas de los manuscritos del Liber feudorum maior y la pintura mural y sobre tabla contemporánea (frontales de altar y baldaquinos) son evidentes. El elemento clave es el Dominus (también la Theotokos) que, desde una posición frontal, recibe el homenaje del vasallo, del fiel cristiano (Figs. $13^{46}$ y $14^{47}$ ). Junto a los ejemplos mencionados, la

${ }^{46}$ Un personaje arrodillado en la parte inferior se inclina a los pies del Señor en actitud de proskinesis (De Scripturis Patrum ad perfectam contemplativam vitam, ACA, Ms. Ripoll, 214 fol. 6v.). Contiene la llamada Theoria de Juan de Fécamp, encabezada por la habitual dedicatoria a la Emperatriz Inés, viuda de Enrique III (PL 147, 445ss). La actitud del orante se corresponde con la actitud, al modo bizantino, de saludar a un superior, inclinando más o menos la cabeza y el cuerpo, en función del respeto que exija quien es saludado. En este caso, se trata de una bazeia proskinesis y se corresponde con cierto número de las pequeñas escenas de salutación entre Gregorio Niseno y Gregorio Nacianceno, que aparecen en los ejemplares ilustrados de las Homilías de san Gregorio Nacianceno (Por ejemplo, Jerusalén Patr. Lib. Cod. Taphou 14, fol. 219 y Bibl. Vat. Cod. Gr. 1947, fol. 104. Ambas ilustraciones están publicadas por George Galavaris, The Illustrations of the Liturgical Homilies of Gregory Nazianzenus, Princeton University Press, 1969, pp. 54-55). Sobre comentarinc acerca de la proskinesis y su representación plástica en las escenas de la epifanía, ver: I. Bango, Sobre el origen de la proskinesis en la epifanía de los Magos, "Traza y Baza", 7 (1978), pp. 25-37. Obra general dedicada a la proskinesis y a su relación con la iconografía imperial: A. GRABAR, L'Empereur dans l'art Byzantine, París-Estrasbourg, 1939. Ver también: A. CUTLER, Transfigurations, "Studies in the Dynamics of Byzantine Iconography”, Pennsylvania University, 1975.

${ }^{47}$ Una de las escenas apocalípticas de la Biblia de Rodas (inicios del siglo XI), en las que aparece el Pantocrátor aureolado por un doble halo circular de luz, de claro sabor clásico, puede ser paralelizada con esta (Biblia de Rodas, París, Bibl. Nat., Ms. Lat. 6, Cristo Pantocrátor rodeado de los siete candelabros, CR X, p. 298). El texto complementa la imagen, en la que parece como si el joven que se apresta al vasallaje fuera el propio Juan apóstol que recibe la protección del Señor. Da esta impresión porque el texto adjunto aparece redactado en primera persona, de acuerdo con el libro del Apocalipsis: "Ecce veniet in nubibus et videvit eum omnis occulus et qui eum pupugerunt et plangent se omnis tribus terre aeciam Amen. Ego sum alpha et omega principium et finis dicit dominus qui est et qui erat et qui venturus est omnipotens (...) Et conversus sum ut viderem vocem que loquebatur mecum et vidim septem candelabra aurea et in medio septem candelabrorum aureorum similem filio hominis vestitum phodere et precinctum ad mamillas zona aurea caput autem eius et capilli erant candidi tamquam lana alba et tamquam nix et occuli eius velut flamma ignis et pedes eius similiter auri calco sicut in camino ardentis et vox illius tamquam vox aquarum multarum (...)" (Ap. 1, 7-15.) "El cabello de su cabeza era como lana blanca como la nieve, y sus ojos como fuego ardiente" (...). "A su derecha, siete estrellas; de su boca una doble espada, y su rostro brillando como el sol en su máximo esplendor. En su presencia, caí como muerto a sus pies y, tomándome con su mano derecha me dijo: no temas, porque yo soy antes que todo y soy el fin de todo, y yo vivo. Como ves, yo vivo, habiendo superado la muerte hasta el final de los tiempos, y tengo las llaves de la muerte y del infierno. Escribe esta visión y lo que ocurrirá a partir de ahora. El significado de las siete estrellas que has visto a mi derecha, y el de los siete candelabros de oro es el siguiente: las siete estrellas son los siete ángeles de las siete iglesias, y los candelabros, siete en número, son las siete iglesias" (Ap. 1, 14-20). Todos los elementos del texto aparecen en la imagen: los candelabros, las espadas, las 
iconografía de la portada de Ripoll abona la hipótesis de que un arte de la Palabra memorizada durante siglos es un potente generador simbólico de poder feudal. La forma de arco de triunfo de esa entrada al monasterio rivipullense, conmemorativa, seguramente, de las gestas de Ramón Berenguer IV en Tortosa y Lleida, es un significativo icono de poder asociado al juramento. La iconografía del triunfo del Pueblo de Israel sobre los amalecitas que ahí se recoge no hace sino confirmar un arte de la Palabra del juramento entre Dios y su Pueblo frente a los enemigos de la fe y, por analogía, entre el pueblo cristiano catalán, vasallo del conde, y los musulmanes expulsados de sus plazas fuertes al sur del Llobregat ${ }^{48}$. Tal vez el aglutinante teológico que sintetiza el juramento y la memoria del poder es la imagen del Pantocrátor que preside estas composiciones (Fig. 15) ${ }^{49}$. Es posible interpretarla como una concentración iconográfica de este mensaje en la persona del Logos inscrito en la mandorla de luz, expresiva de la eficacia de una verdadera teología del vasallaje.

\section{EL JUICIO COMO MEMORIA DEL VERBO}

La abundancia de la iconografía del juicio final en la Cataluña del siglo XII remite, sin lugar a dudas, a un acordarse del Verbo-Cristo. Una forma de memoria del juicio funal la constituye, sin duda, el Canto de la Sibila en Cataluña ${ }^{50}$. Se trata de un canto celebérrimo en la Edad Media, de gran influencia educativa y en la ejecución del cual intervino activamente el pueblo. Los versos Judicii signum ya alegados en griego por Constantino en el concilio de Nicea (325), traducidos al latín por san Agustín en La Ciudad de Dios, fueron ejecutados después de la sexta o novena lección de los

estrellas, las llaves y el contexto de luz sugerido por ese doble globo de luz.

${ }^{48} \mathrm{Cf}$. F. Rico, Signos e indicios en la portada de Ripoll, Barcelona, Fundación Juan March, 1976; A. PUIGARnau, Catalan Mediaeval Chronicle as a Biblical Icon of Political Power, en "Proceedings of the $2^{\text {nd }}$ Conference 'The Medieval Chronicle' ", Utrecht (The Netherlands), pp. 16-21 July 1999. En prensa.

${ }^{49}$ Monasterio de Ripoll. Portada. Siglo XII, detalle del Pantocrátor.

${ }^{50}$ Sobre este tema las referencias serían innumerables. Me remito a un importante artículo de B. MCGINN, Teste David cum Sibylla: The Significance of the Sibylline tradition in the Middle Ages, en B. MCGINN, Apocalypticism in the Western Tradition, Hampshire, Variorum, 1994, pp. IV , 7-35. Originalmente publicado en J. KIRSHNER; S.F. TEMPLE, Women of the Medieval World, en "Essays in honor of John H. Mundy", Oxford, Basil Blackwell, 1985. 
maitines de Navidad en Francia ${ }^{51}$, Italia, Castilla ${ }^{52}$ y principalmente en Cataluña ${ }^{53}$. Desde sus inicios, se maneja el texto latino ${ }^{54}$ y sólo más tardíamente, desde el siglo XIII, es cantado en lengua vernácula en Francia, Provenza y Cataluña, donde perdura oficialmente hasta el siglo XVP5.

El canto sibilino experimenta su desarrollo al mismo tiempo que otros elementos relacionados con una teología de la luz, directamente asociada a la Palabra del juicio final. No parece casual que estos versos aparezcan en el mismo marco de celebración litúrgica de una misa de Navidad, junto con homilías alusivas al Cristo-Luz ${ }^{56}$ y a gran cantidad de iconografía apocalíptica. Efectivamente, al final del sermón nocturno de los maitines de Navidad, se añaden los versos sibilinos por los cuales, además del anuncio del Mesías, se profetiza el segundo advenimiento del Cristo en el fin del mundo. Son los

${ }^{51}$ A. GastouÉ, Le Cantique Populaire en France, Lyon, 1924; F. RAUGel, Le Chant de la Sibylle d'après un manuscrit du XII siècle conservé aux Archives de l'Hérault, en "Actes du Congrès d'Histoire de l'Art”, París, 1921 (París, 1923-1924), vol. III, pp. 774-783.

${ }^{52}$ M.C. GómEz MunTaNÉ, El canto de la Sibila, I: León y Castilla, Madrid, Alpuerto, 1996; R.B. Donovan, The liturgical Drama in Mediaeval Spain, Toronto, 1958.

${ }^{53}$ M.C. GómEz MuNTANÉ, La música medieval, Barcelona, Dopesa 2, 1980, pp. 31-55.

${ }^{54}$ Para el texto latino ver: CHEvalier, Analecta hymnica, IV, $\mathrm{n}^{\circ} 9876$, p. 15; DrEves, Cantiones Bohemicae, p. 107; PL 42,1117ss, donde se encontrará el Sermo de Symbolo del Pseudoagustín, Contra Judaeos, del cual se utilizaba los capítulos XI-XVI para la última lección del segundo nocturno de los maitines de Navidad.

55 "Sibillae carmina et pastorum nugas, aliasque vulgares cantilenas, nullo tempore in ecclesiis cani permittantur", dicen las Sinodales de Tarragona de Antoni Agustí. Cf. D. COSTA I BORRÀS, Obras, IV, p. 281; VILlANUEVA, Viage literario a las Iglesias de España. Le publica con algunas observaciones Don Joaquín Lorenzo Villanueva, Madrid, Imprenta Real, 1803-1852., XXII, p. 185.

${ }^{56}$ Por ejemplo, la coincidencia de la Homilía al prólogo del Evangelio de Juan (escrita por Escoto Eriúgena) y el Canto de la Sibila, en un mismo pliego de manuscritos. Cf. Montpellier, Archives départamentales de l'Hérault, Lectionnaire de l'office divin, fol. $52 \mathrm{v}-54 \mathrm{v}$, del s. XII. La Vox spiritualis es anónima e incompleta. Se interrumpe en las palabras: perfidos inuasit arrianos, protinus adiecit: et deus erat verbum (VI, 24). Se encuentra su reseña en: E. AUDE, Note sur une version provençale du Chant de la Sybille, d'après un manuscrit conservé aux Arxives départamentales de l'Hérault, en "Annales du Midi. revue de la France méridionale" 17 (1905), pp. 380-385; F. RAUGEL, Le Chant de la Sybille d'après un manuscrit du XII siècle conservé aux Archives de l'Hérault, en "Actes du Congrès d'Histoire de l'art organisé par la Societé de l'histoire de l'art français" (Paris, 26 septembre-5 octobre 1921), t. 3, II, 2, Paris, 1924, pp. 774-783 y t. 4 (vol. de láminas), pl. 96 (reproducción fotográfica del fol 52r-52v): H. ANGLES, La música a Cataluña fons al segle XIII, Barcelona, 1935, pp. 292, 294, 296, 301. 
mismos versos que san Agustín encajaba en su Ciudad de Dios al hablar de la Sibila Eritrea como testimonio profético del Cristo que vendría ${ }^{57}$.

Es importante destacar la tradición manuscrita de este documento litúrgico, ya estudiada por Higini Anglès y $\mathrm{M}^{\mathrm{a}}$ Carmen Gómez. En latín hay abundancia documental: en Córdoba, un curioso ejemplar del siglo $\mathrm{X}$, correspondiente a la liturgia visigótica, aun cuando lleva una notación parecida a la aquitana de los manuscritos catalanes ${ }^{58}$; el que procede de Ripoll, también del X, reproducido por Anglès ${ }^{59}$, el de París, llamado Collectaneum, originario de san Marcial de Limoges ${ }^{60}$. Del siglo XI, un Lectionarium conservado en París ${ }^{61}$; otro manuscrito que no ofrece el añadido del Pseudoagustín $^{62}$, el de Saint Marcial ${ }^{63}$, y otro leccionario catalán del mismo siglo ${ }^{64}$, además del de la Colegiata de san Félix de Girona ${ }^{65}$ Del siglo XII: el Lectionarium de Montpellier ${ }^{66}$ y otros ${ }^{67}$. El texto latino aparece reproducido en la obra de Anglès, teniendo en cuenta las variantes de los manuscritos conocidos, fechados entre los siglos X y XIII' ${ }^{68}$. Es preciso ver el canto de la Sibila en el contexto más amplio de los dramas litúrgicos medievales en el siglo XII, y aun de la historia general de la música en Cataluña. Ya en los

${ }^{57}$ Sobre su origen oriental y su relación con el tema apocalíptico en relación al Emperador: B. MCGINN, The Erythraean Sibyl, en "Apocaliptic Traditions in the Middle Ages", , New York, Columbia University Press, 1979, pp. 122-125.

${ }^{58}$ Córdoba, Catedral sign. I (olim 72), Homiliarium, fol. 69b, H. ANGLÈs, La música a Cataluña fins al segle XIII, Barcelona, Biblioteca de Cataluña i Universitat Autònoma de Barcelona, 1988.

${ }^{59} \mathrm{ACA}$, Ripoll 106, fol 92v, en ANGLÈs, 1988.

${ }^{60}$ PBN lat. 1154, fol. 122a, Collectaneum, siglo X, ANGLÈs, 1988.

${ }^{61} \mathrm{PBN}$ lat. 5304, fol. 112v, siglo XI, ANGLÈs, 1988.

${ }^{62} \mathrm{PBN}$ lat. 2832, fol. 123v, s. XI, ANGLÈs.

${ }^{63} \mathrm{PBN}$ lat. 1139, fol 58, s. XI, ANGLÈs, 1988.

${ }^{64} \mathrm{PBN}$, Lat. 5302, fol. 82, siglo XI, ANGLÈs, 1988.

${ }^{65}$ Girona, Colegiata de san Félix, Antiphonarium, s. XI, fol. 21v: Alme rex Criste nunc noster quoque alleluya; Lumen de lumine adesto Criste...

${ }^{66}$ Montpeller, Archives de l'Hérault. Lectionarium, s. XII, fol. 52, ANGLÈs, 1988.

${ }^{67}$ ANGLÈs, 1988, p. 292.

${ }^{68}$ ANGLÈs, 1988, p. taula I. 
siglos IX y X la riqueza de libros litúrgicos es notable en la Marca Hispánica ${ }^{69}$.

Tal vez analizando brevemente la versión vernácula, se pueda dar una idea de la práctica popular de esta arraigada devoción y de su relación con la idea de Juicio como una manifestación más de este arte de la Palabra. "Ell iorn del judizi para qui aura fag servizi (Judici signum: tellus sudoret madescet ${ }^{70}$ ), es la primera imprecación, a la que se contesta: Us reis venra perpetuals Del cel ques anc non fon aitals: En carn venra sertanament, Per far del segle jugamen (Ecce lo rex adveniet per secla futurus, Scilicet in carne presens ut iudicet ordem ${ }^{71}$ ). Y otra vez se repite: Ell iorn... ${ }^{72}$. Evidentemente, tras este texto, y tras la conciencia de los que lo cantan, hay un espíritu de Juramento: Dios ha prometido un juicio para quien le haya servido (servizi), explicita el texto. La relación con Dios se estetiza de un modo paralelo a como se producen las relaciones entre los hombres: el vasallo, la creatura, presta un homenaje (immixio manuum y juramento, básicamente); y Dios protege $\mathrm{y}$, finalmente, juzga. La actitud de las imágenes de los primeros condes catalanes en los sellos condales manifiesta este paralelismo (fig. 16) (3) $^{73}$ entre una prestación de homenaje y una protección señorial. De hecho, parece como si las autoridades civiles aprovecharan el imaginario cristiano del momento para, imitando la actitud de juicio del Pantocrátor-Luz, apropiarse de unos atributos que, desplazados desde el campo de lo sagrado, les sirvan para conseguir sacralizar su propia autoridad sobre el vasallo.

"El día del juicio, para quien haya servido", es la expresión inicial, a la que se contesta: "Un rey vendrá perpetuo, del Cielo como no lo hay tal".

${ }^{69} \mathrm{H}$. ANGLÈs, La música a Cataluña fins al segle XIII, Barcelona, Diputación de Barcelona, Publicaciones de la Sección de Música de la Biblioteca de Cataluña, 1935, pp. 118 ss.

${ }^{70}$ Barcelona, ACA, Ripoll 106, fol. 92v, Collectaneum, s. X.

${ }^{71}$ Girona, Bibl. Sombola, fol 8, lectionarium, s. XII.

${ }^{72}$ Texto del Lectionarium del siglo XII con añadidos del XIII, según el Ms. de Montpellier.

${ }^{73} \mathrm{El}$ conde-rey sedente en un banco con cojín, lleva corona y manto, con su mano derecha empuña la espada levantada y sostiene con la izquierda una flor de lis. Inscripción: + SIGILLVM ILLDEFONSI REG(is Ar)AG(onen)SIS. Reverso: El conde-rey a caballo, que marcha al pas en dirección hacia la derecha del sello. Con llambreguins muy alargados, y empuña una lanza con señera. El escudo que lleva es muy alto y acaba en punta en la parte inferior. Tanto en éste como en la señera de la lanza, como en la gualdrapa que cubre el caballo se ven definidas las barras, aunque estrechas, a manera de rayas verticales. Inscr.: COMOTIS BARCHINONENSIS ET MARCHIONIS PROVINCIE. Fechado en Narbona en mayo de 1186. 
Y continúa: "En carne vendrá ciertamente ${ }^{74}$, para hacer el juicio del siglo". Es un ritmo alternante que transmite la sensación dramática de la prisa por salvarse. El concepto de drama místico asociado al del juicio se desarrolla insistentemente en la literatura patrística de la época ${ }^{75}$. A modo de ejemplo, se puede citar a Juan Escoto:

\begin{abstract}
El Padre, tal y como él afirma, no juzga a ningún hombre pero ha dado todo juicio al Hijo. Sin embargo, (...) sólo el Padre conoce el Juicio futuro no sólo por conocimiento del futuro, sino por experiencia, porque el Padre conoce el Juicio por experiencia desde que era una realidad en el momento de entregar este juicio al Hijo, porque el Padre ya había juzgado antes de entregarle el juicio al Hijo. El hijo, por otra parte, a la vez conoce y desconoce acerca del Juicio. Porque sabe de él por conocimiento futuro, pero no por experiencia. Y la razón por la que no lo conoce por experiencia es que el juicio, que es la segregación de los reprobados, de entre los elegidos, no es un hecho consumado, porque la cosecha de la Iglesia es todavía una mezcla de trigo y paja ${ }^{76}$.
\end{abstract}

La definición de Juicio es casi violenta: "La segregación de los reprobados" (segregatio reproborum ab electis). Un manuscrito de la catedral de Vic ofrece una versión de la Sibila que se sitúa en el contexto de una teología de la luz a través del fuego de Dios: Et coram hic domino reges sistentur ad unum: Decidet e celo ignisque et sulphuris amnis ${ }^{77}$; la Sibila de Montpellier, que aparece, como se ha dicho, en el mismo pliegue de manuscritos que la Homilía del Escoto, ofrece una teología de la luz/tiniebla todavía más explícita: Eripitur solis iubar, et chorus interit astris. Volvetur celum lunaris splendor obibit ${ }^{78}$.

Al hablar de un arte de la Palabra de poco serviría citar textos más o menos eruditos, de poca circulación en la Cataluña del siglo XII. Son muchos los manuscritos que se manejan en la época alusivos al juicio como memoria del Verbo encarnado. El siglo XII es tiempo de reformas litúrgicas y morales. s. XIV).

${ }^{74}$ En algún documento se dice: Vestit de nostra carn mortal (Palma de Mallorca, Cantorale,

${ }^{75} \mathrm{~B}$. McGinn, The Growth of Mysticism, vol. II of The Presence of God: A History of Western Christian Mysticism, London, SCM Press, 1995, p. 98-118.

${ }^{76} \mathrm{PL} 122,595 \mathrm{~B}$.

${ }^{77}$ Vic, Catedral, Lectionarium, s. XII.

${ }^{78}$ Montpellier, Archives de l'Hérault, s.s., f. 52, Lectionarium, s. XII. 
Es un período situado entre dos papas de fuerte personalidad como Gregorio VII e Inocencio III, que marcan un cierto auge en la Iglesia con anterioridad al siglo del cisma de Occidente. Entre fines del XI e inicios del XIII se uniformiza la liturgia romana y, entre otras cosas, se define el dogma de la transubstanciación eucarística (IV Concilio de Letrán, 1215). La producción iconográfica relativa al juicio final es abundante en estas épocas. Sin embargo, la composición y el canto de los versos sibilinos son un testimonio que va más allá de acontecimientos, por decirlo así, minoritarios. El canto de la Sibila es una cristianización de época tardoantigua de usos populares paganos que, recibida en la Cataluña del siglo XII, experimenta una recepción extraordinaria. Repetir un estribillo como el de Ell iorn del judizi para qui aura fag servizi a voz en grito, año tras año, representa una auténtica Memoria del Juicio, una vez más, elemento estructurador del Arte de la Palabra en esta época de la Cataluña condal. Más arriba se ha dicho que el Juramento es una "palabra de ida", mientras que el Juicio es "palabra de vuelta". Lo que narra el canto de la Sibila son los avatares de la "Palabra de vuelta". El canto sibilino da voz a la iconografía del pantocrátor esculpido en tímpanos y pintado en ábsides de la geografía del Principado catalán. Es cierto que el hieratismo del Logos del Padre aureolado por una mandorla mística podía resultar incomprensible para algunos. Sin embargo, usos litúrgicos como el Canto sibilino, traducidos tempranamente a lenguas vernaculares, iluminan los misterios del arte y despiertan la memoria de los fieles de un modo a la vez dramático y asequible para todos.

\section{CONCLUSIÓN}

Una Cultura de la Palabra es la que se ha estudiado en el presente artículo. Se ha intentado explicar que esta cultura cristaliza, en el espacio y en el tiempo, en dos conceptos clave: el Juramento como estructurador de poder feudal y el Juicio como catalizador de un sentimiento religioso. En la articulación de estos dos conceptos ha sido fundamental un tercero: la Memoria como potencia cognoscitiva que crea y recrea constantemente un poder feudal (derivado del juicio) y una cultura religiosa apocalíptica (explicitada en la iconografía del juicio final). Lo que se ha pretendido en estas páginas es explicar el Juramento como memoria de esta Palabra generadora de poder feudal. El pacto feudovasallático es una ceremonia 
sacramental, que remite a la Palabra de Dios. Es un pacto generador y estructurador de una malla social de poder. Es fundamental considerar el Juicio como memoria soteriológica. Es preciso recordar la primera Palabra en Cristo: el bautismo. Esta "memoria sacramental-baptismal" remite, ciertamente, a un Juicio final. Los programas iconográficos del Apocalipsis son una memoria, un recuerdo de nuestros orígenes y una remisión a nuestras postrimerías: despiertan una memoria y apuntan a un final de los tiempos. Siempre hay un Alfa y un Omega: nadie escapa a este sino. Finalmente, la Memoria del Juramento y del Juicio va siempre ligada al Tiempo. El tiempo es la Memoria de la Palabra: acordarse del Verbo es lo que mide el tiempo. Así se vinculan el Juramento, el Juicio y el Tiempo: mediante el Anno domini, en el que cristaliza definitivamente esta Memoria de la Palabra en la Cataluña del siglo XII.

Sea como fuere, en este trabajo se ha intentado algo que va más allá de la inspiración historicista, recelosa de los métodos de la historia de la cultura. Hemos querido "ilustrar el espíritu de la época con las voces y las formas del espíritu mismo y, por tanto, eliminar el yo, como fuente principal de errores, de la investigación entre la palabra, la acción y la imagen"79. Esto ha obligado al historiador del arte a abandonar las generalidades de la Geistesgechichte (historia del espíritu) y a concentrarse en el individuo como tal y en las imágenes individuales. De ahí el tipo de fuentes empleadas en este intento de explicar un arte de la Palabra durante el siglo XII en Cataluña: homiliarios, epigrafía asociada a la obra de arte, imágenes de la época, sacramentarios, antifonarios, evangeliarios, himnarios y, como es natural, abundante bibliografía sobre el tema. Se ha tratado, por lo tanto, de intentar ver en todas las representaciones icónicas el reflejo de las imágenes mentales, Vorstellungen (anticipos de la idea). Se ha intentado algo que quedaba prometido en la introducción al trabajo: postular, como hábito mental de la época, una facilidad para "recordar inventivamente", una verdadera "Memoria creativa" que posibilita la actividad y la actualidad de una Palabra de fuerte sabor cristológico; encontrar, en cada detalle fáctico que ofrece la historia, el principio general que bajo él subyace.

${ }^{79}$ E.H. GoMBrich, Aby Warburg. Una biografia intelectual, Madrid, Alianza, 1992, pp. 288- 


\section{RÉSUMÉ}

Cet article propose une approche culturelle à quelques manuscrits et images artistiques du XII ${ }^{\text {ème }}$ siècle catalan. Ces pages relèvent d'une intention de dépasser l'historicisme et constituent un essai de vérifier jusqu'à quel point il est possible de réaliser une histoire de la culture médiévale catalane d'un point de vue plus herméneutique. Des sources primaires telles que manuscrits liturgiques, peintures murales, frontals d'autel et inscriptions, sont utilisées pour mieux comprendre le fait que au-delà de cette "culture matérielle" il existe une "habitude mentale" dans le déploiement d'idées culturelles et religieuses mises en liaison avec trois idées principales: une conception particulière du serment féodal, générateur de forts liens de pouvoir entre le seigneur et son vassal; une mentalité scathologique qui songe au Jugement dernier dans un contexte apocaliptique; et une connection spéciale entre ce Serment et ce Jugement au travers de notions comme la Mémoire et le Temps. L'idée centrale qui relie ces quatre éléments (serment, jugement, mémoire et temps) c'est un Art de la Parole.

Cette "parole" est ici considérée comme conséquence esthétique du fait de l'Incarnation du Christ comme Logos et Sagesse, adorée dans l'image iconographique du Pantocrator (omnipotens) au cours du Moyen Âge européen.

\section{SUMMARY}

In this article the author deals with a cultural aproach of some manuscripts and artistic images during the $12^{\text {th }}$ century in Catalonia. Behind this pages there is an intention of not no aproaching to the so called Historicism and to check to what extent it is possible to make a History of Medieval Catalan Culture from a more hermeneutic point of view. Primary sources as liturgical manuscripts, wall paintings, altar pannels and inscriptions are used in order to understand the fact that behind all of these 'material culture' there is a "mental habit" of producing cultural and religious ideas in connection with three main aspects: a particular conception of the feudal Promise creating strong relations of power between lord andvassal; a schatological mentality of being at lastjudged in an Apocalyptical context; and a particular connection of these Promise and Judgement through concepts as Memory and Time. The principal issue that is embodying feudal Promise, last Judgement, Memory and Time is the Art of Word, considering this 'word' as an aesthetic consequence of the historical fact of the Incarnation of Christ as Logos and Wisdom believed as Pantocrator (Omnipotens) during the whole European Medieval period. 


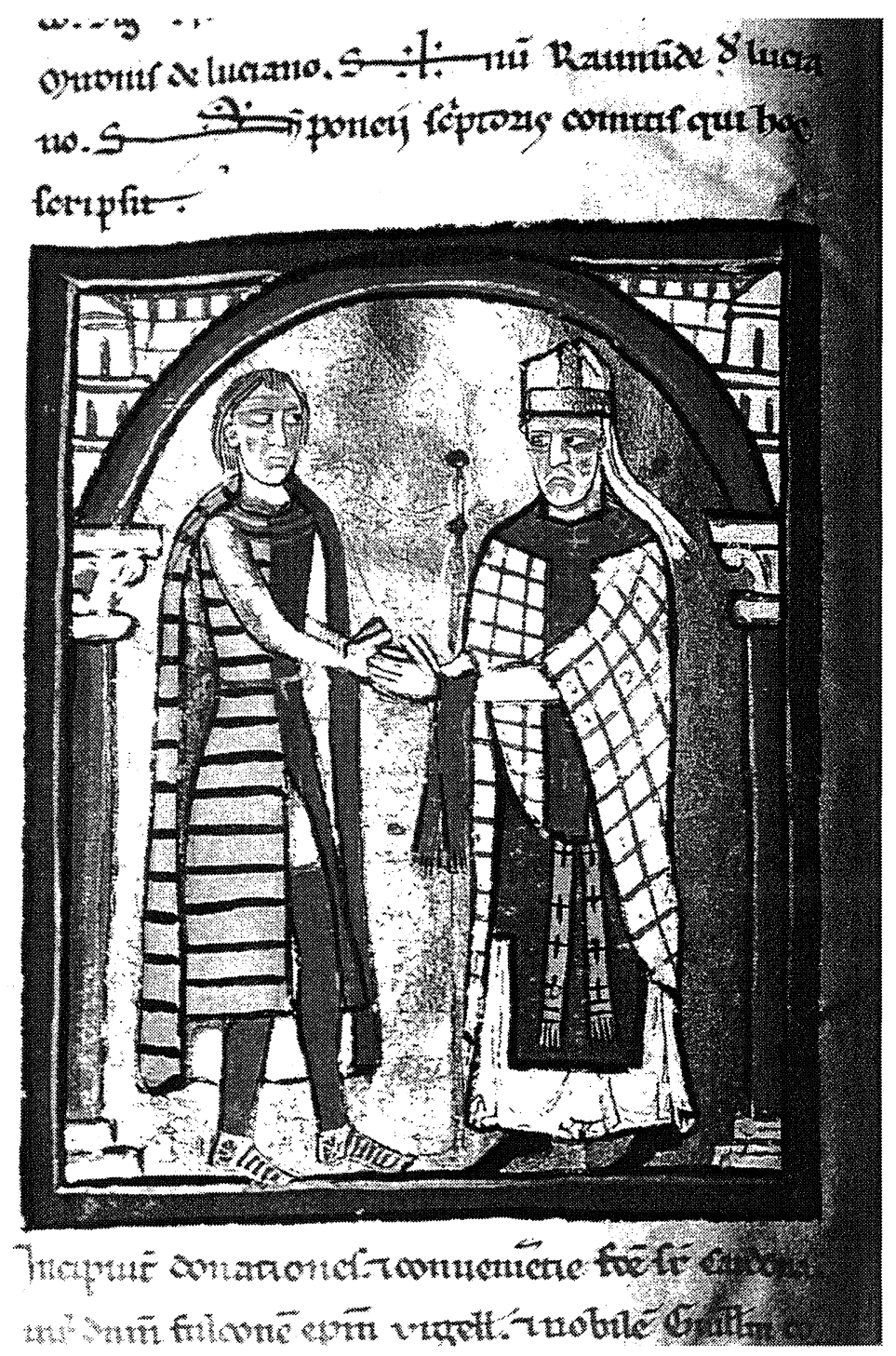

Fig. 1. Convenio sobre el castillo de Cardona apararecen su señor, el obispo Folch de Urgel, y el conde Guillem Ramón de Cerdaña, LFC, fol. 6 d. Cf. LFM, II, lám. VI, CRXX, p. 49. 


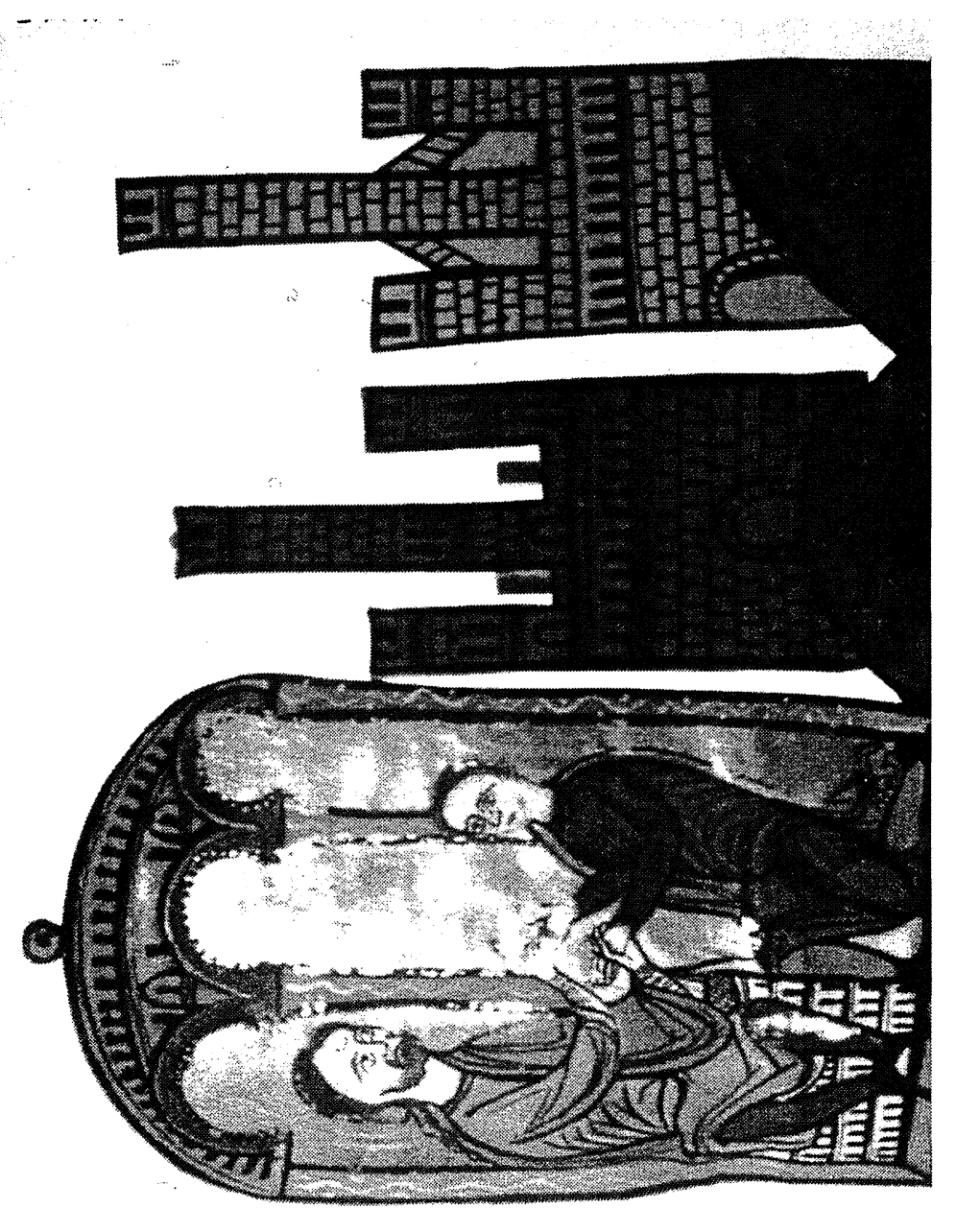

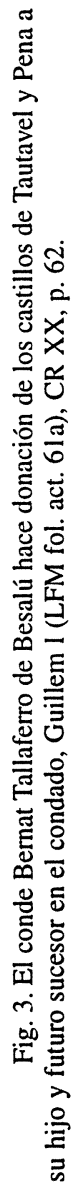




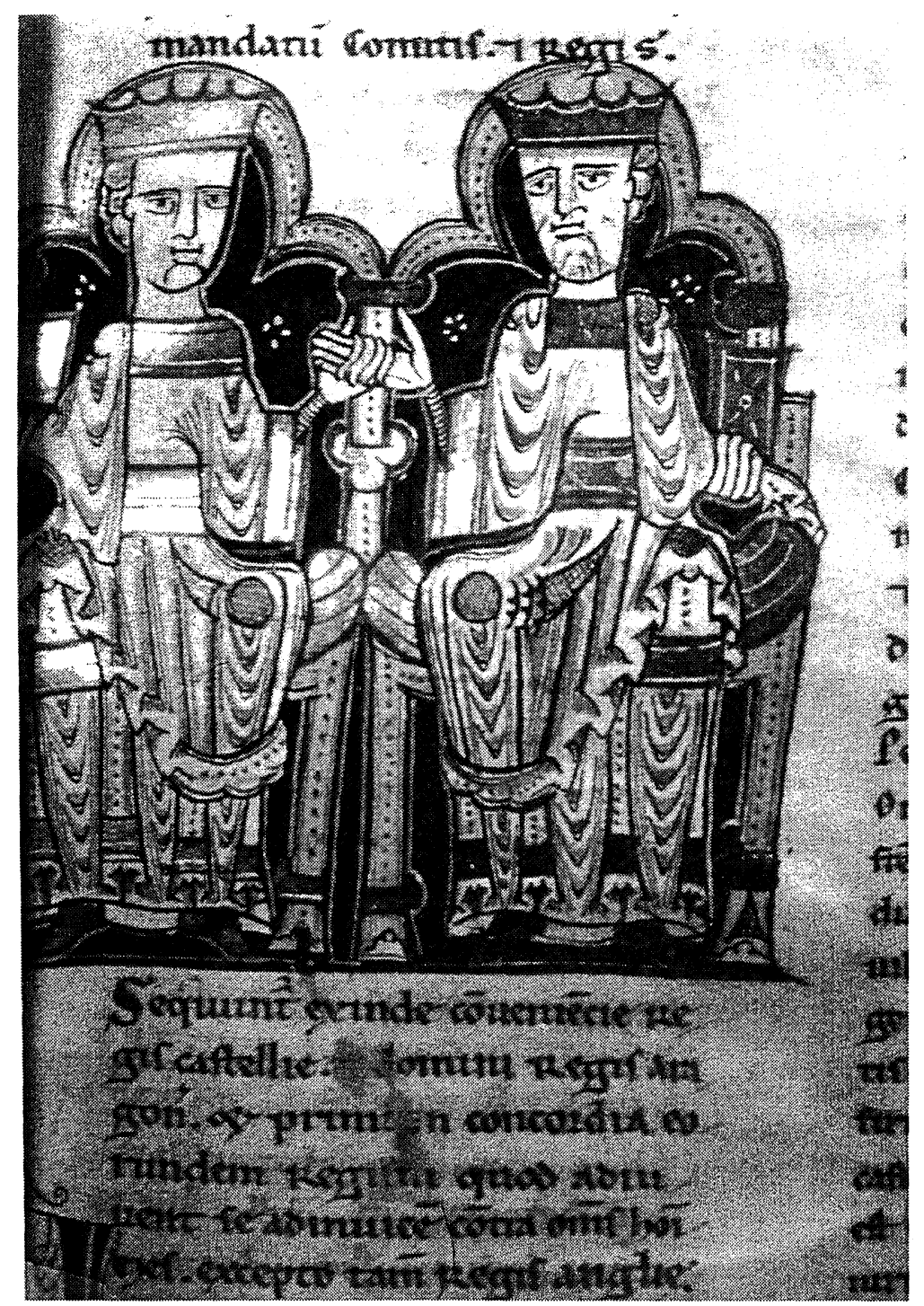

Fig. 4. Los dos Alfonsos, el Casto y el de las Navas, pactan mútua ayuda. Tratado de Zaragoza, julio de 1170, LFM, fol act. 19, CR XX, p. 198. 


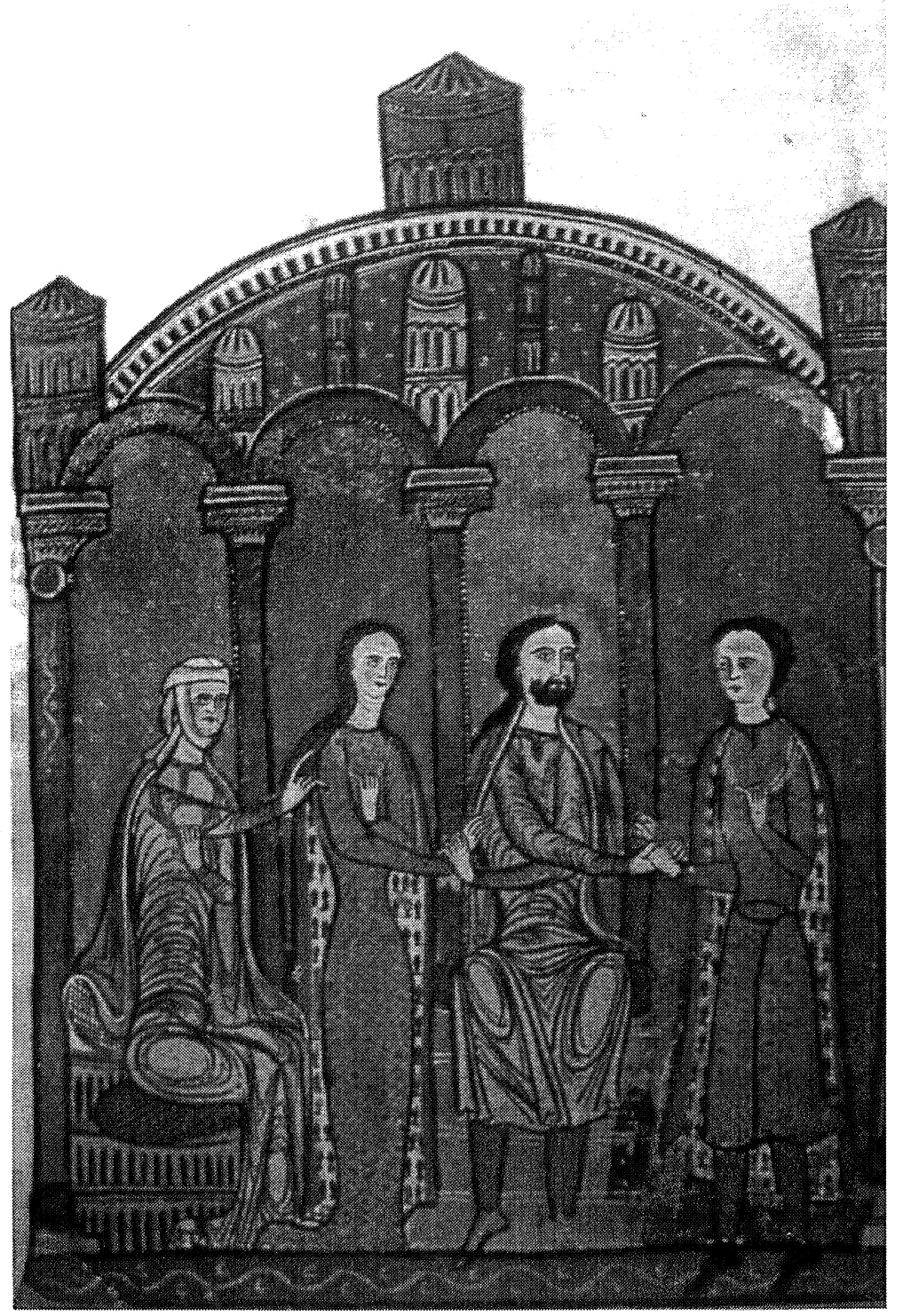

Fig. 5. El vizconde Bernat Ató de Béziers y Cecilia, su esposa, entregan, jủntamente con su hija Ermengardis, varios feudos, como dote esponsalicia, al futuro conde Gausfred III, de Rosellón, LFM, fol.act. 78v, CR XX, p. 200. 


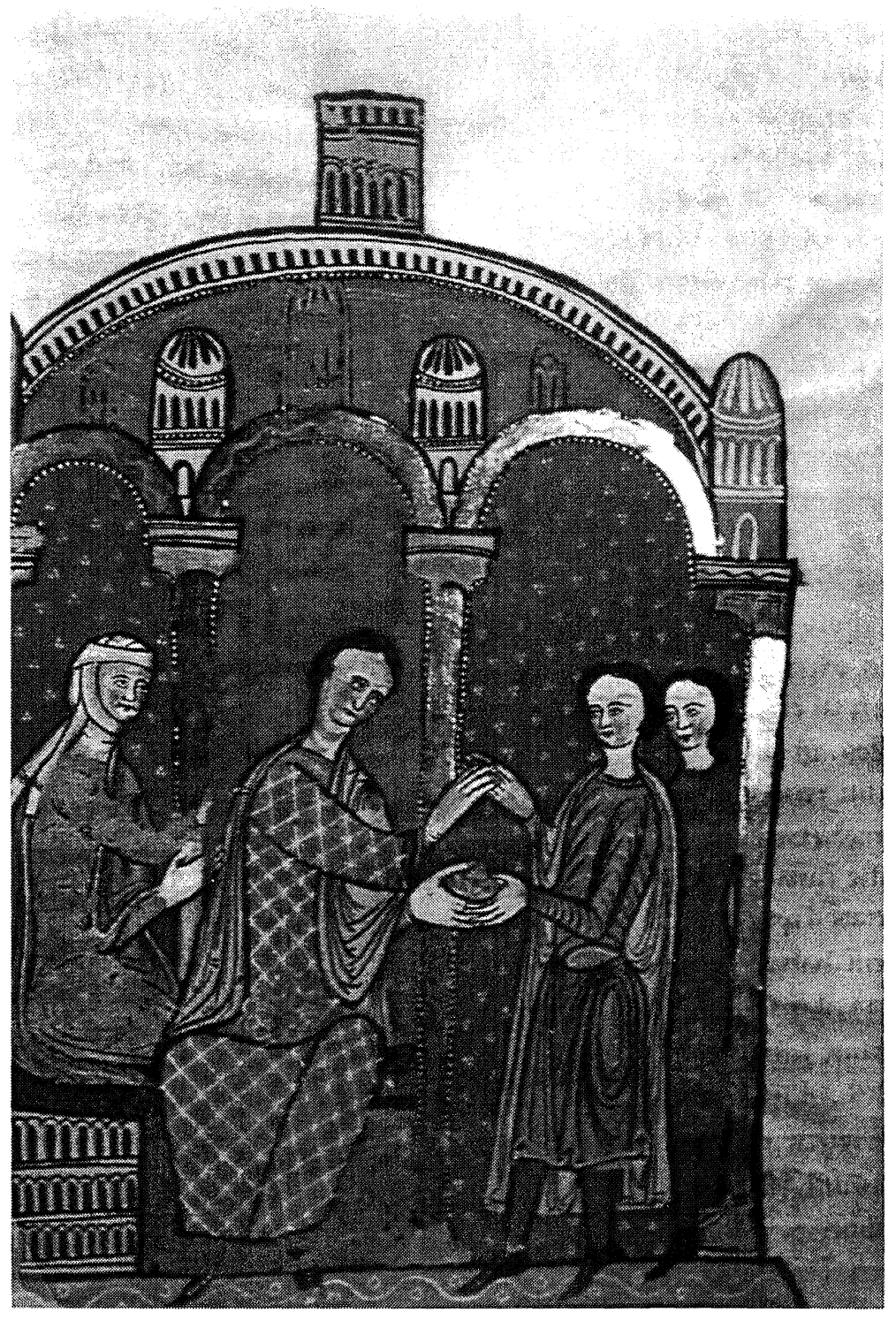

Fig. 6. Acto de entrega de dos mil onzas de oro, hecha por Ramón Berenguer I y Almodis, su esposa, al conde Guillem Ramón de Cerdaña y a Adelaida, su esposa, por la cesión de sus derechos sobre Carcasona, LFM, fol. act. 83bis., XX, p. 201. 


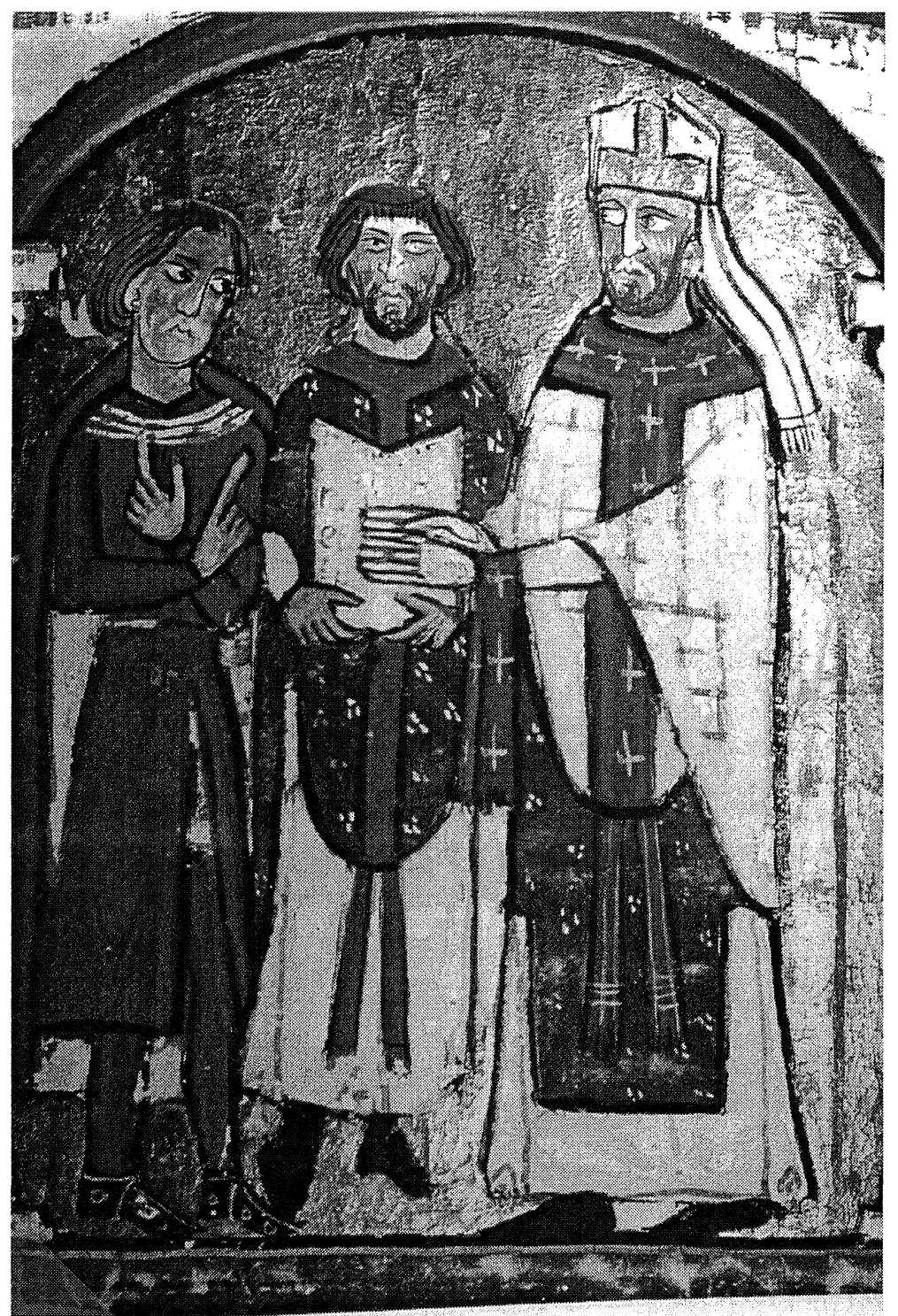

Fig. 7. Juramento de fidelidad prestado por el obispo san Armengol de Urgel al conde Guifré de Cerdaña, LFC, fol act. 9d, CR XX, p. 204 


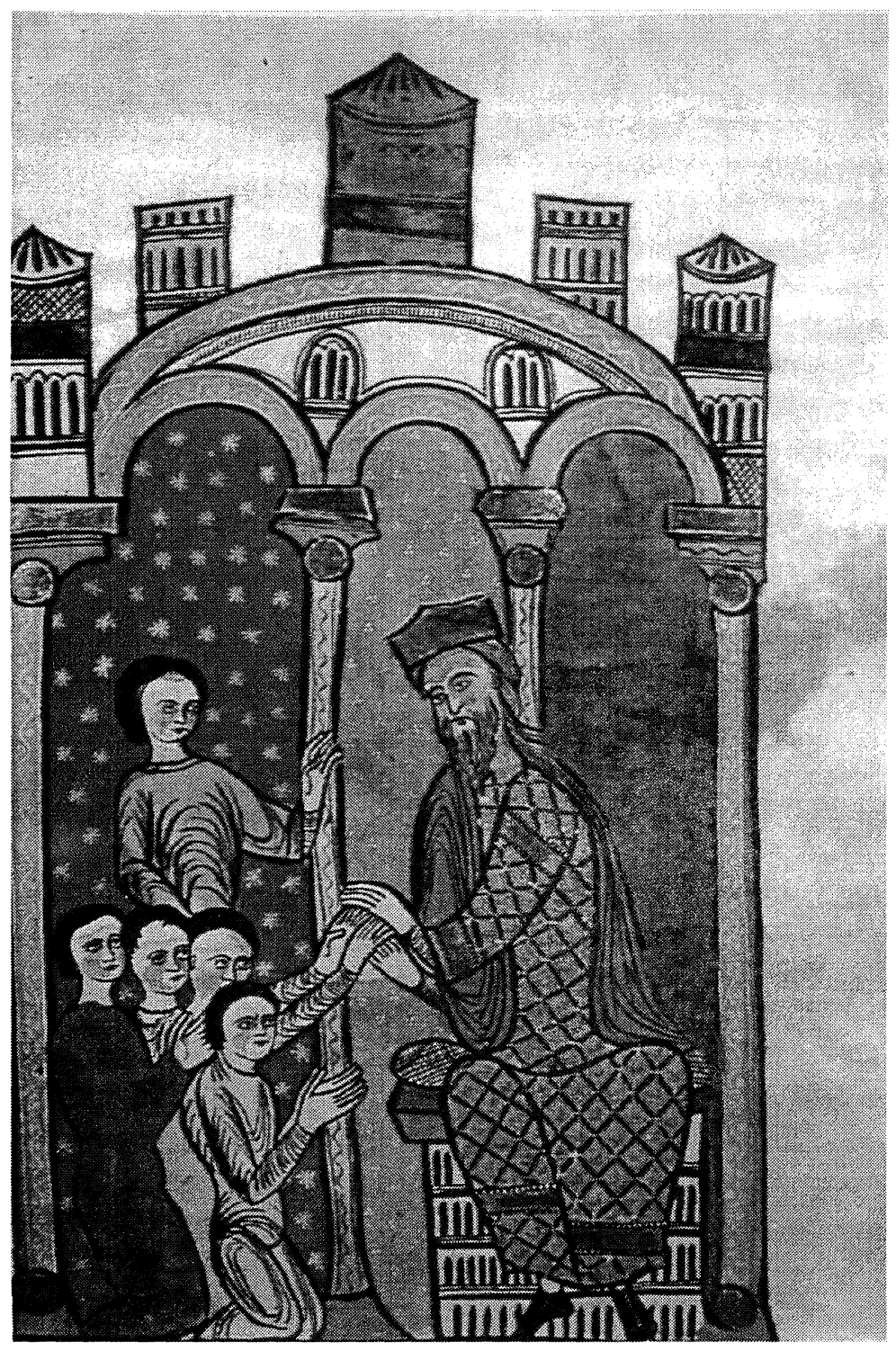

Fig. 8. Los nobles de Perpignan juran fidelidad a Alfonso el Casto, al igual que los castellanos del condado de Rosellón, LFM, fol act. 82, CR XX, p. 199 


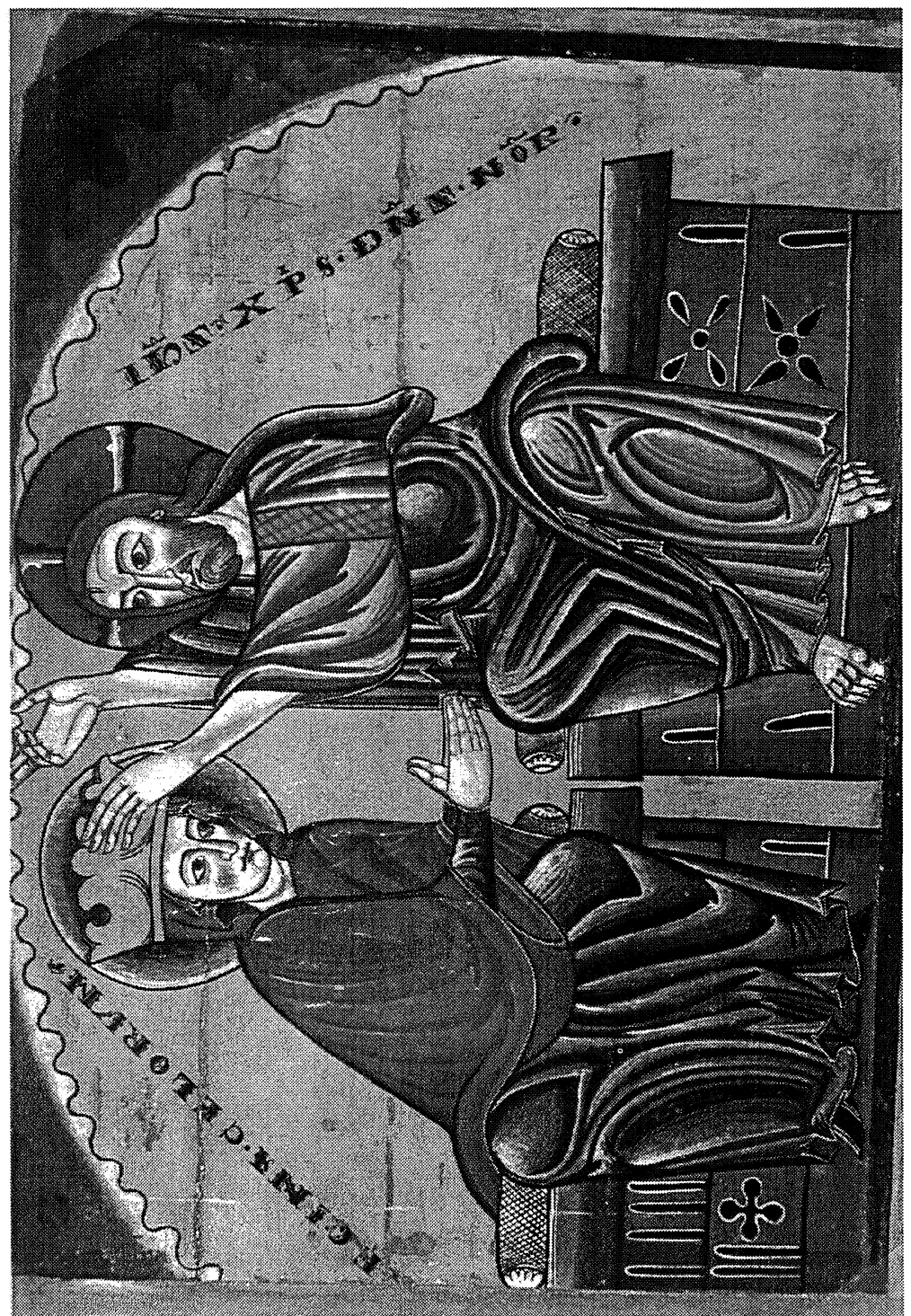

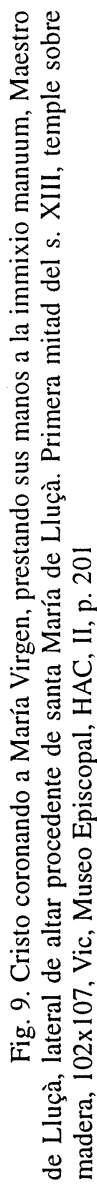




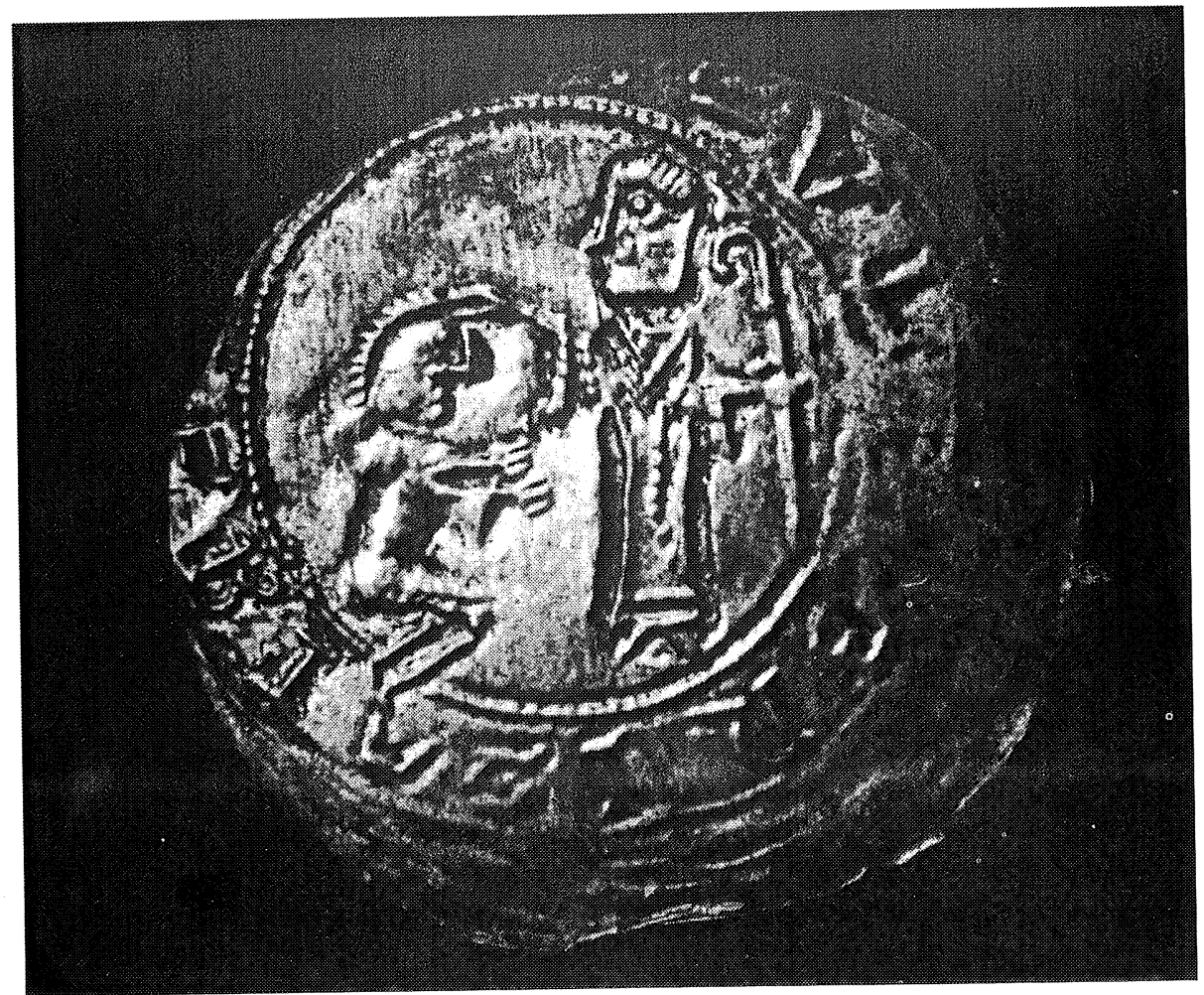

Fig 10. Moneda Polonia (Gniezno), Boleslas III, de uso ritual, acuñada en el siglo XII. Emitida en honor de san Adalberto. Letras deformadas, pero en la mayor parte de los casos dicen: BOLEZLAVS ADALBERTVS. Parece la prestación del homenaje feudal, con las manos cerradas ofreciéndoselas a un obispo, Ph. Grierson, Monnaies du Moyen Age, Fribourg (Suisse), Office du livre, 1976, n. 250. 


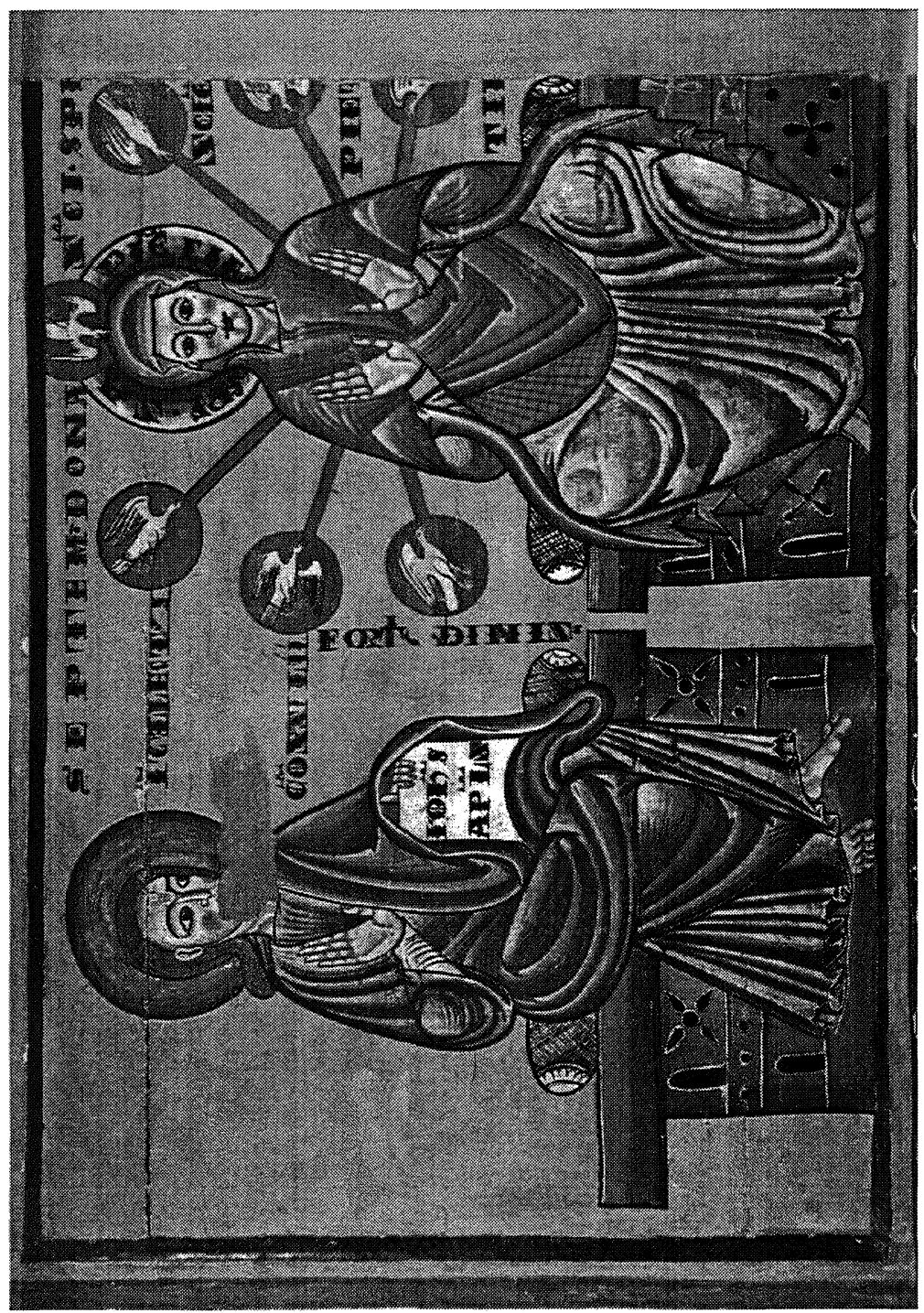

兽

음

은 잉

एँ

氖

焉険

总的

㤩虽

出

区

造

용

을

을 웜

를

远证

焉这

$\sum_{0}$ क

尊兽

政

三茫

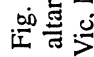

동

㐌 


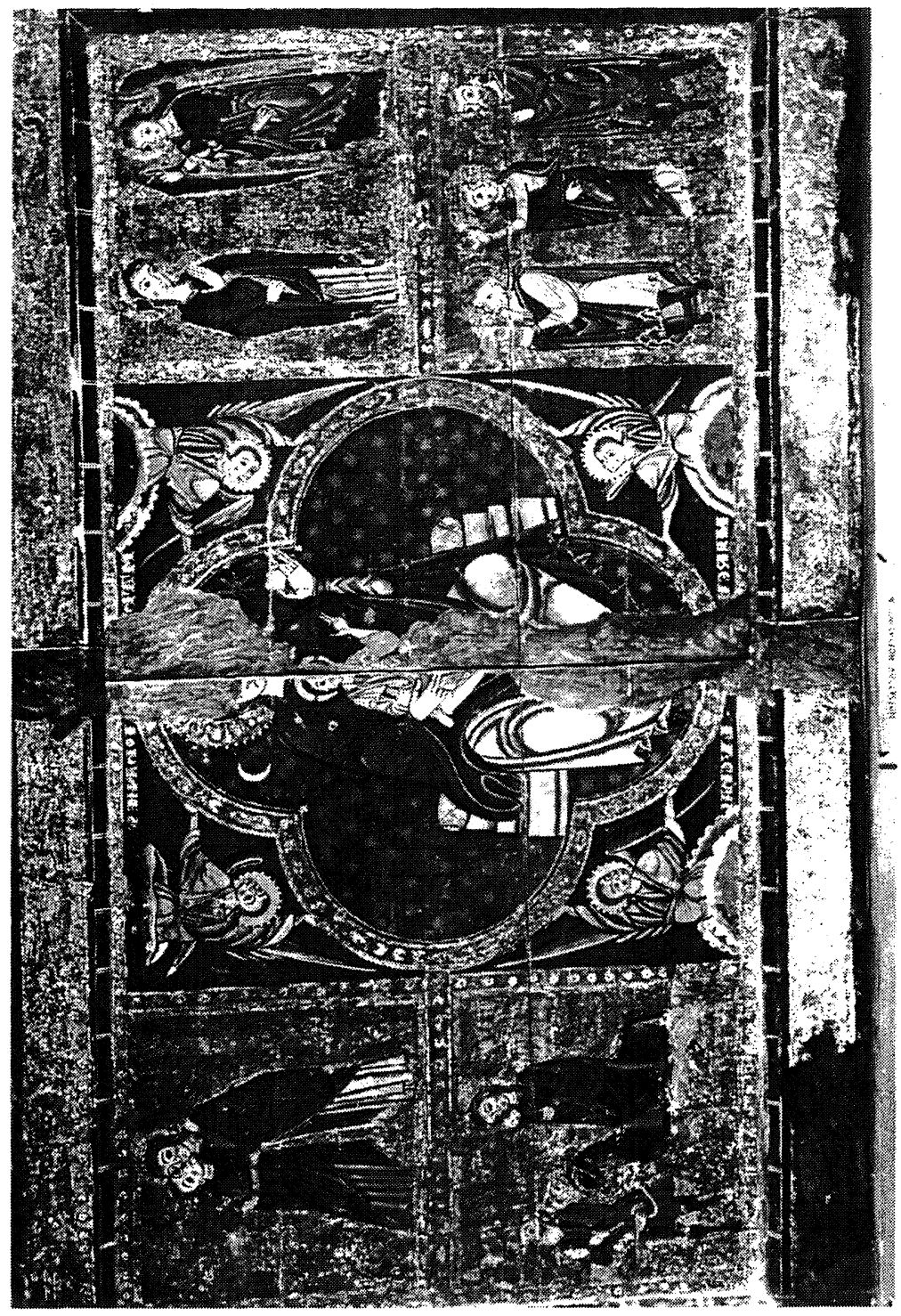

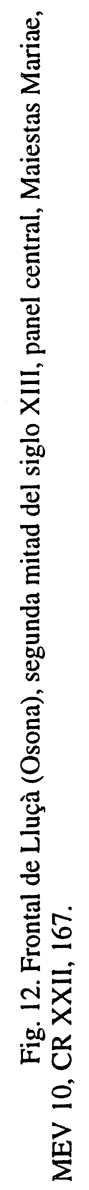




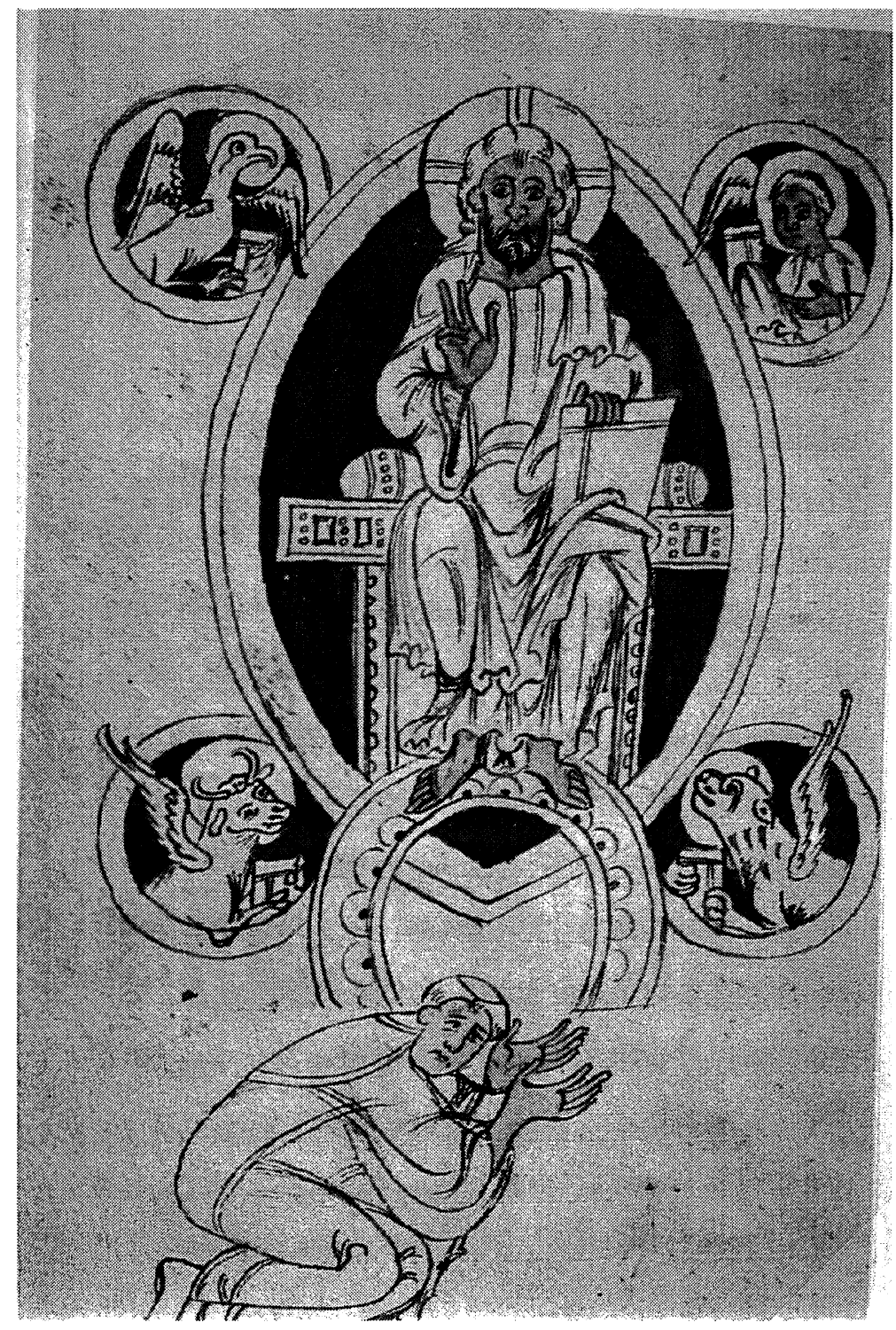

Fig. 13. Un personaje arrodillado en la parte inferior se inclina a los pies del Señor en actitud de proskinesis (De Scripturis Patrum ad perfectam contemplativam vitam, ACA, Ms. Ripoll, 214, fol. 6v.). 


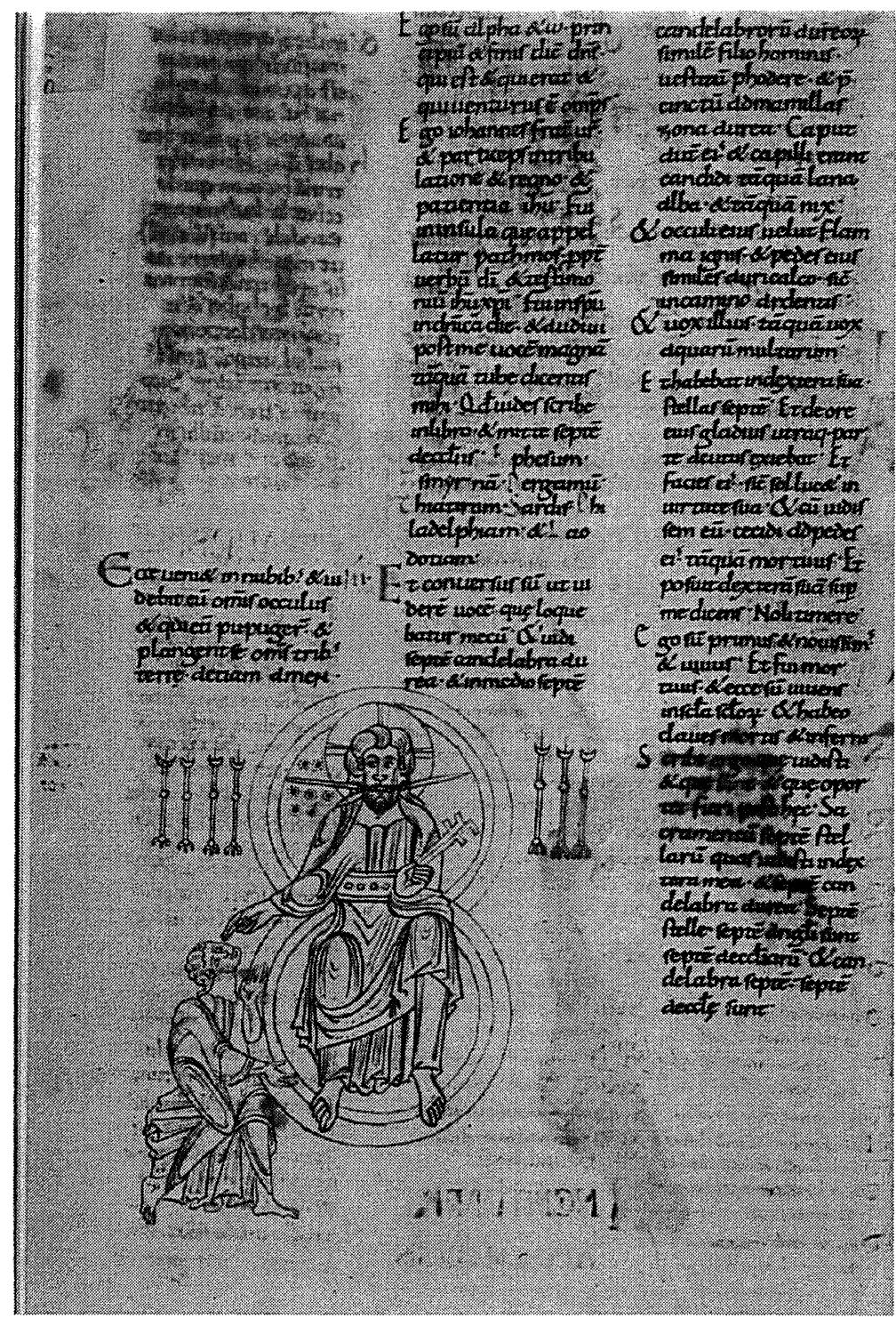

Fig. 14. Una de las escenas apocalípticas de la Biblia de Rodas (inicios del siglo XI), en las que aparece el Pantocrátor aureolado por un doble halo circular de luz, de claro sabor clásico, puede ser paralelizada con esta (Biblia de Rodas, París, Bibl. Nat., Ms. Lat. 6, Cristo Pantocrátor rodeado de los siete candelabros, CR X, p. 298). 


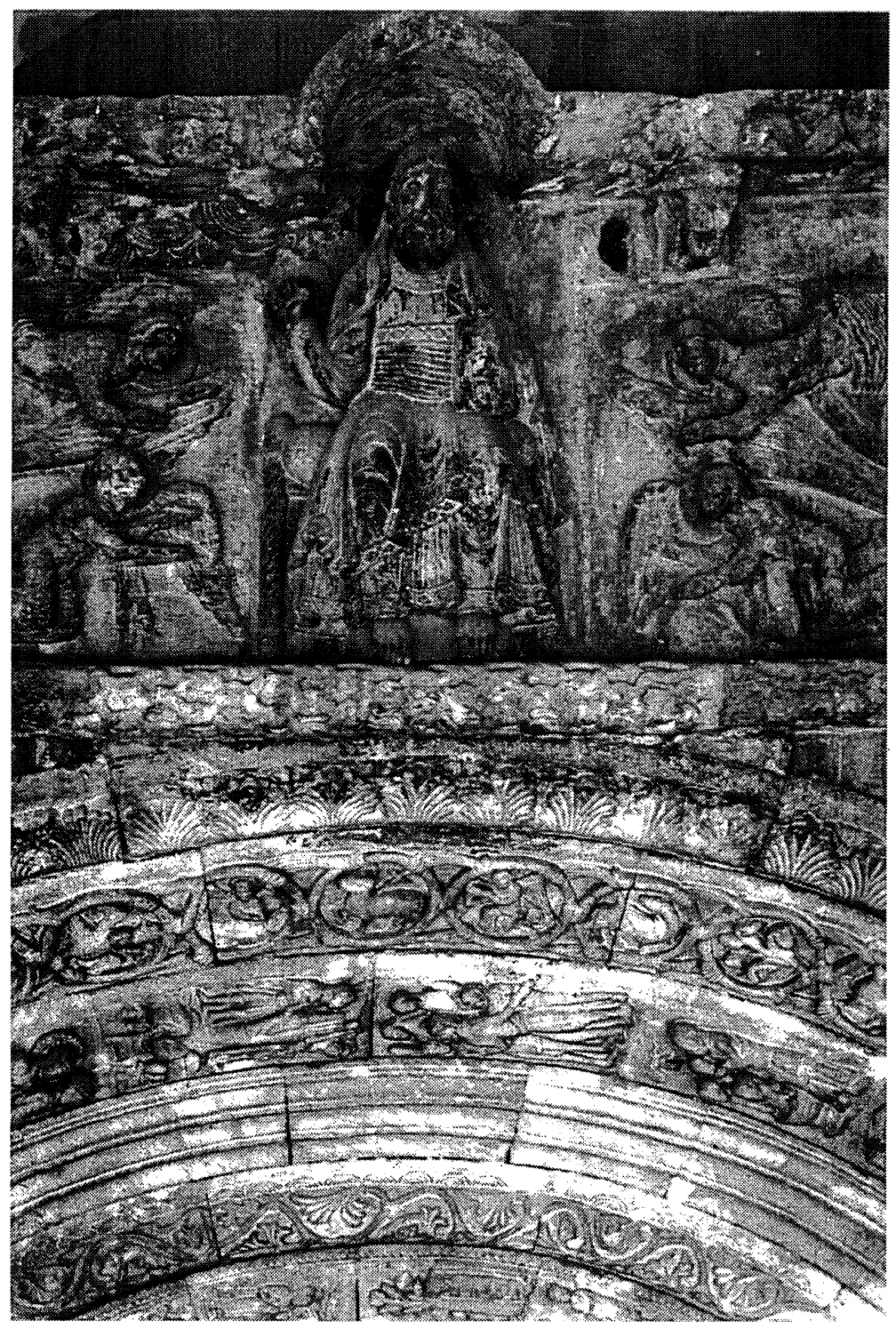

Fig. 15. Monasterio de Ripoll. Portada. Siglo XII. Detalle del Pantocrátor. 